\title{
THEORETICAL AND EXPERIMENTAL EVALUATION OF TIMBER-FRAMED PARTITIONS UNDER LATERAL DRIFT
}

\author{
Jitendra Bhatta ${ }^{1}$, Joshua Mulligan ${ }^{2}$, Rajesh P. Dhakal ${ }^{3}$, \\ Timothy J. Sullivan ${ }^{4}$, Hans Gerlich ${ }^{5}$ and Frank Kang ${ }^{5}$
}

(Submitted August 2020; Reviewed October 2020; Accepted December 2020)

\begin{abstract}
This paper identifies the inherent strengths/weaknesses of rigid timber-framed partitions and quantifies the onset drifts for different damage thresholds under a unidirectional quasi-static cyclic loading. It reports construction and testing of a multi-winged timber-framed partition wall specimen, with details typical of New Zealand construction practice. As the tested subassembly included four partition wall wings oriented along four different directions, bi-directional performance of the tested wall system could be assessed despite the loading being unidirectional. Furthermore, the tested rigid timber-framed partition wall's cyclic performance is also compared with that of similar partition walls incorporating "partly-sliding" connection details and "seismic gaps", previously tested under the same test setup.

Theoretical equations proposed/derived in the literature to predict the ultimate strength, initial stiffness, and onset drifts of different damage states are scrutinized based on the experimentally recorded cyclic performance measures. Some equations are updated in order to alleviate identified possible shortcomings. These theoretical estimates are then validated with the experimental results. It is found that the equations can reasonably predict the initial stiffness and ultimate shear strength of the partitions, as well as the onset-drifts corresponding to the screw damage and diagonal buckling failure mode of the plasterboard.
\end{abstract}

\section{INTRODUCTION}

Non-structural elements (NSEs) include secondary systems or components attached to the floors, roofs, and walls of a building or industrial facility that are not explicitly designed to participate in the main vertical or lateral load-bearing mechanism of the structure. Nevertheless, NSEs are required to accommodate the effects of seismic actions such as drifts and accelerations [1]. Typical examples of NSEs include internal non-loadbearing partitions, suspended ceilings, sprinkler piping systems, architectural claddings, building contents, mechanical/electrical equipment, and furnishings. They play a major role in the operational and functional aspects of buildings and contribute a major portion of the building's overall cost [2-5]. Therefore, they are expected to remain intact and usable during and after earthquakes, particularly in vital facilities such as hospitals, police and fire stations, power stations, communication centres, and government offices $[1,6,7]$. However, in past earthquakes, in addition to causing some injury/casualties, financial losses (including repair costs and disruption/downtime) due to non-structural damage were reported to have been higher than those caused by structural damage [7-11]. Within the broad spectrum of NSEs, suspended ceilings, piping, and partition walls were identified as significant contributors to the financial loss following earthquakes $[3,9,12,13]$.

During the 2010-11 Canterbury Earthquake Sequence (CES) in New Zealand (NZ), non-structural damage was observed to be more extensive than structural damage [14-17]. As traditionally constructed rigid partition walls are drift-sensitive components with low deformation capacity, they can suffer damage at relatively small drifts. Consequently, internal gypsum-plasterboard lined partitions were unable to accommodate the drift demand imposed by the primary structures and suffered wide-ranging damage [14,18]. Survey results reported damage to internal lightweight partitions in $74 \%$ of internally inspected commercial buildings within the greater Christchurch area following the 2010-11 CES [14]. Damage commonly included screw failure, diagonal cracks or detached sheets from framing, compression damage of linings, or anchorage failures between partition framing and the main structure. These damages often required costly and intrusive repairs or replacement of entire walls [19-21].

Along with cold-formed steel, timber has been a dominant framing material for internal partition walls in commercial buildings in NZ [22,23]. Interior partitions are commonly constructed with gypsum-plasterboard linings on both sides of the steel or timber frame and are usually not intended to act as shear walls. However, due to their presence in abundance, their cumulative lateral strength and stiffness are found to alter a building's dynamics, especially under low-level seismic excitation [24].

A timber-framed interior partition generally consists of timber studs and plates sandwiched between gypsum plasterboard linings on both sides. Gypsum plasterboard is a machine-made product and consists of a gypsum core encased between cardboard liners on both faces [25]. It is one of the most ubiquitous lining materials because of its availability, low-cost, and speed and ease of installation. Gypsum plasterboard is usually secured to framing using either nails or screws and/or adhesives [26-

\footnotetext{
${ }^{1}$ Corresponding Author, PhD Candidate, University of Canterbury, Christchurch, jitendra.bhatta@pg.canterbury.ac.nz.(Student Member)

2 Masters' in Civil Engineering, University of Canterbury, Christchurch, j.mulligan@harrisongrierson.com

${ }^{3}$ Professor, University of Canterbury, Christchurch, rajesh.dhakal@canterbury.ac.nz (Fellow)

${ }^{4}$ Professor, University of Canterbury, Christchurch, timothy.sullivan@canterbury.ac.nz.(Member)

${ }^{5}$ Industry Partners from Winstone Wallboards Ltd. (GIB), New Zealand, hansg@gib.co.nz and frank.kang@gib.co.nz
} 
28]. The final finishing includes stopping/plastering (usually two-three coats), sanding and finally painting (usually two coats) [29].

This study reviews several experimental tests, and theoretical analyses of internal plasterboard partition walls reported in the literature that evaluate: 1) initial stiffness of the walls, 2) ultimate shear strength of the walls, 3) drift at the onset of damage of the plasterboard screws, and 4) drift at out-of-plane buckling of the plasterboard sheets.

Additionally, a rigid timber-framed specimen, typical of commercial partition walls in NZ, was constructed in a "y" shape and tested with technical advice and support from New Zealand gypsum plasterboard manufacturer Winstone Wallboards Ltd. [26]. The test aimed to: 1) observe the bi-directional performance of a common timber-framed partition wall with return walls, 2) obtain drifts at which different damage states occur, 3) verify theoretical predictions of the damage states, and 4) formulate a capacity-based approach to control the cracks in the plastered joints and screw failures along the joints.

The same test-setup was previously used to investigate the performance of steel stud interior partitions with "partly-sliding" details [30]. The specimen layout/configuration was similar to the timber-framed specimen. The load-deformation hysteretic curves, onset drifts at damage thresholds, damage progressions, energy dissipations, secant stiffness degradations, and equivalent viscous damping coefficients for the two partition systems are also compared in this paper. Furthermore, the seismic performance of these specimens is briefly compared with those of low-damage partition walls incorporating "seismic gaps" [31], which were also tested under the same setup.

\section{LITERATURE REVIEW}

The purpose of this section is to review the published research on experimental tests and theoretical analyses investigating the strength, stiffness, deformation, and damage-states of timberframed partition walls.

\section{Experimental Tests on Partition Walls}

The earliest experimental studies of timber-framed partitions [32-38] focused on understanding their seismic behaviour by investigating the contribution of different sheathings (gypsum plasterboard, oriented strand board, plywood) and their orientation, wall openings, interior and external finishes, type and spacing of screws and boundary restraints (such as return walls, ceiling cornices, and skirting) on the lateral load resistance and failure mode of the walls. The tests conducted by Arnold et al.[39,40] explored the response of timber-framed walls with boundary conditions typical of single-story structures and the first-story walls of two-story structures, in addition to determining the efficacy of various stucco and plasterboard repair methods.

Van de Lindt [41], and Memari and Solnosky [42] examined the effect of multiple earthquakes on the in-plane strength and stiffness of isolated timber-framed walls and assemblies with plasterboard corners and returns. They investigated the extent of damage to these wall configurations as well as the effects of the cement and non-cement-based drywall joint compounds on the shear strength of plasterboard joints and junctions. They concluded that the type of joint compound could have a significant effect on the shear strength of gypsum plasterboard assemblies.

Tasligedik [43] tested a timber-framed wall with gypsum plasterboard on both sides, enclosed in a concrete main frame. The specimen showed brittle behaviour with severe damage occur- ring at $0.75 \%$ inter-story drift under quasi-static in-plane cyclic loading.

\section{Theoretical Analysis of Partition Walls}

The shear strength of an internal partition wall is commonly predicted based on the shear strengths of the screw between the sheathing and internal framing $[44,45]$. The type of frame and the spacing of framing members are not expected to significantly contribute to the bracing strength of the wall [46]. It is generally observed that the screw failures occur around the wall perimeter and at the top and bottom runners (or plates) [47-50]. It has been assumed that the lateral force acting on the top runner of the wall is transferred to the sheathing through the top screws and to the bottom runner by the screws at the bottom boundary, as shown in Figure 1.

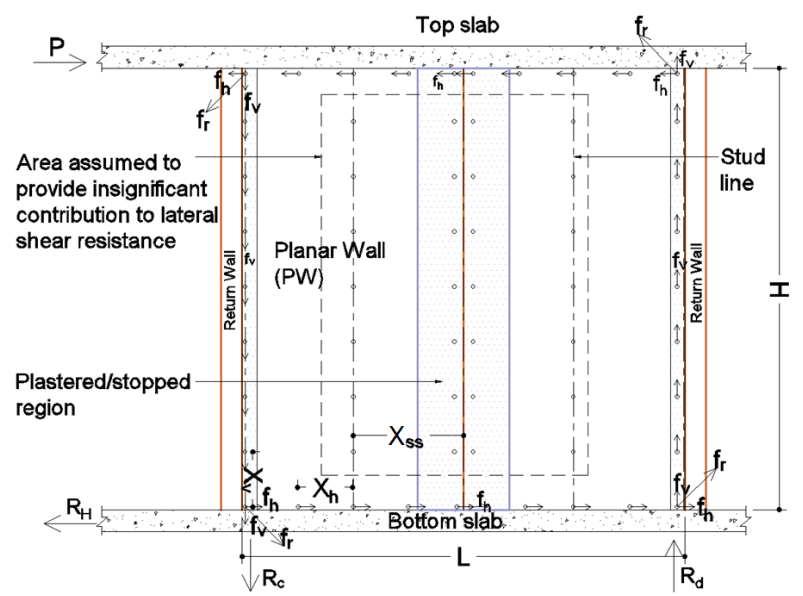

Figure 1: Schematic diagram of force transfer through a rigid partition wall.

The shear strength per unit length of the wall $V_{f r}$, with sheathing on both sides, corresponding to screw damage located at an extreme corner of the partition wall is given by [44,51]:

$$
V_{f r}=\frac{2 f_{r}}{\lambda}
$$

where $f_{r}$ is the shear strength of the screws between the frame and the sheathing, and $\lambda$ is a factor dependent on the geometrical properties of the wall and horizontal and vertical screw spacing.

$$
\lambda=\sqrt{\left(L / n_{h}\right)^{2}+\left(H / n_{v}\right)^{2}}
$$

where $L$ is the length of the wall, $H$ is the height of the wall, $n_{h}$ is the number of screws in the top or bottom horizontal boundaries of the partition wall, and $n_{v}$ is the number of screws in the left or right vertical boundaries of the partition wall.

From past experimental results, it is found that the shear strength $f_{r}$ of gypsum plasterboard-to-timber screws (with screw gauge numbers 6,8 and 10) is $0.5 \mathrm{kN}$ [44,47,52-54] and $0.66 \mathrm{kN}$ [53] for single and double-layers of $10-12 \mathrm{~mm}$ boards, respectively. However, overdriven screws and saturated/soaked plasterboard can reduce the shear strength $f_{r}$ of the connections by a factor of 1.3 and 4, respectively [55]. There are several published articles from which the values of $f_{r}$ can be obtained [47,52-54]. One of the examples of the screw-slip curve is shown in Figure 2. In this figure, the maximum load in the screw is its shear strength, and screw slip is the relative displacement between the plasterboard and the screw in the loading direction. 


\section{Local Buckling of Plasterboards}

Local buckling of horizontally oriented gypsum plasterboards was observed by Golledge et al. [44] in a partition wall with return ends, as shown in Figure 3. The plasterboard section buckled when the acting axial load exceeded the buckling load of the plasterboard. In their study, the buckling load was calculated as:

$$
P_{\text {buckling }}=\frac{k}{X^{2}}
$$

where $k$ is a proportionality constant based on the buckling load obtained from the experiment and $X$ is the horizontal spacing between the screws.

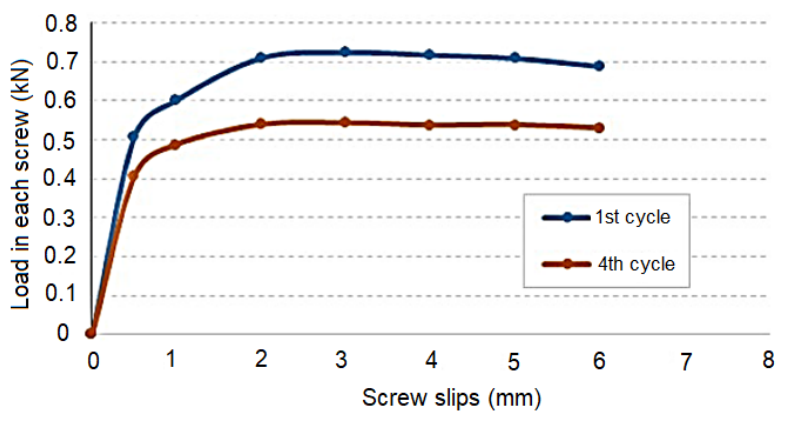

Figure 2: Example of a screw-slip curve from several tests on timber-frame [54].

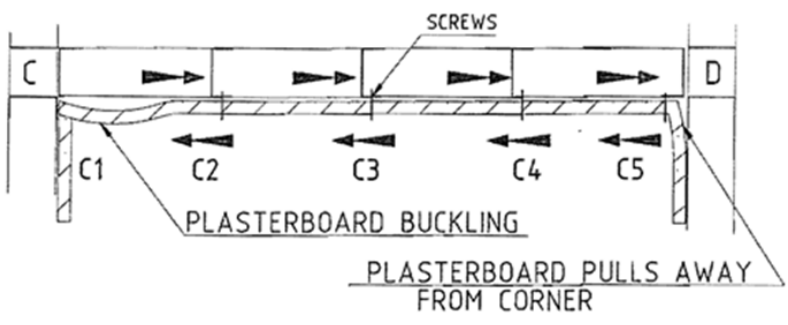

Figure 3: Sectional plan view showing the failures of plasterboard [44].

As the screws are driven only into the vertical studs, $X$ is taken as equal to the stud spacing $X_{S S}$.

Now, equation 3 can be generalized using Euler's buckling load where the critical buckling load in an axially loaded column (in this case, plasterboard) is given by [56],

$$
P_{c r}=\frac{\pi^{2} E I}{\left(K X_{s s}\right)^{2}}
$$

where,

$X_{s s}$ is the effective length of the gypsum plasterboard taken equal to the horizontal spacing between the studs;

$K$ is an effective length factor taken equal to 0.7 assuming a fixed-pinned boundary condition; and

$E I$ is the flexural rigidity of the plasterboard, which can be obtained from GA-235-2019[57]. The typical values of EI are shown in Table 1.

In Table 1, it can be observed that the values of $E I$ vary within a wide range as they depend on the type, thickness, density, and orientation of the gypsum plasterboard, the paper type used to sandwich the gypsum core, relative humidity, and the amount of handling before testing [57]. Therefore, the buckling load is
Table 1: Values of EI [57].

\begin{tabular}{cc}
\hline $\begin{array}{c}\text { Thickness of gypsum } \\
\text { plasterboard }(\mathbf{m m})\end{array}$ & EI $\left(\mathbf{k N} \cdot \mathbf{m m}^{\mathbf{2}} / \mathbf{m m}\right)$ \\
\hline $13 \mathrm{~mm}$ & 220 to 580 \\
$16 \mathrm{~mm}$ & 440 to 1160 \\
\hline
\end{tabular}

difficult to be estimated reliably for plasterboards in a given site condition.

\section{Displacement Analysis}

The total lateral displacement $\Delta_{t}$ in a rigid timber-framed partition wall commonly comprises of: 1) flexural displacement of the frame $\Delta_{f}, 2$ ) shear displacement of the plasterboard $\Delta_{s}, 3$ ) screw-slip due to slippage of screws between the plasterboard and the frame $\Delta_{s s}$, and 4) the displacement of the whole wall due to racking caused by uplifting of bases $\Delta_{r k}$ [51,54,58-61].

$$
\Delta_{t}=\Delta_{f}+\Delta_{s}+\Delta_{s s}+\Delta_{r k}
$$

where:

$$
\Delta_{f}=\frac{P H^{3}}{3 E A L^{2}}
$$

where $P$ is the lateral force acting on the partition wall (it is assumed that the loads are uniformly distributed on both sides of the wall), and $E$ and $A$ are the modulus of elasticity and area of the timber chord, respectively.

2.

$$
\Delta_{s}=\frac{P H}{G L t}
$$

where $G$ and $t$ are the shear modulus ( $\approx 830 \mathrm{MPa}[26,57]$ and thickness of the plasterboard, respectively.

3

$$
\Delta_{s s}=\frac{2 d_{s o} P}{n_{h} f_{r}}(1+H / L)
$$

where $d_{s o}$ is the displacement at which the shear strength of the frame-to-plasterboard screws is reached. The values of $d_{s o}$ can be obtained from screw-slip curves for connections between different types of plasterboards and internal frames. Some values of $d_{s o}$ reported in the literature for screw connection between gypsum plasterboard and timber frame and between type $\mathrm{X}$ gypsum plasterboard and steel frame are $1 \mathrm{~mm}$ [54] and $10 \mathrm{~mm}$ [47], respectively.

$$
\Delta_{r k}=\frac{v_{1}-v_{2}}{L_{12}}
$$

where $v_{1}$ and $v_{2}$ are the vertical uplifts of the wall, respectively, at points 1 and 2 (located in the plane of the wall), and $L_{12}$ is the horizontal distance between points 1 and 2 .

\section{Stiffness Analysis}

Since the plasterboard and plasterboard-to-frame screws are attributed as the major contributors to the wall stiffness [49,53], the equivalent lateral stiffness of a partition wall $K_{e q}$ considering only the shear deformation of the gypsum plasterboard and the screw-slip mechanism is given by [51]: 


$$
K_{e q}=L^{2} /\left(\frac{H L}{2 G t}+\frac{2 d_{s o}\left(H L+L^{2}\right)}{n_{h} f_{r}}\right)
$$

\section{PREDICTION OF ONSET DRIFTS FOR DIFFERENT PARTITION DAMAGE STATES}

In this section, the limitations of the aforementioned formulations and analysis methods are identified. These analysis approaches are amended, where deemed necessary and possible, based on the published research. Moreover, they are applied to approximate the response and damage states, where applicable, of different types of partition walls.

\section{Force Analysis}

The shear strength calculated using equation 1 is conservative for rigid timber-framed walls as it is solely based on the shear strength of screws. It has been observed that the performance of walls generally depends on the type, size, and frequency of the screws (and/or adhesives), type and thickness of the plasterboard and the material properties, hold-down details, and the type of joint finish [32-40,44-46]. It is found that the plasterboard-toframe screws can maintain their load-carrying capacity during the bearing failure of the plasterboard, and as a result, the actual shear strength is higher than that given by equation 1 by a factor of 1.3 [52]. However, this overstrength can be usually negated when the screws are overdriven into the plasterboard [55]. Therefore, to generalize the shear strength of the wall, some factors are introduced in equation 1 to account for the effects of the different partition wall system, types of plasterboard-to-frame connections and types of joint finishes, as shown in equation 11 .

$$
\begin{gathered}
V_{u l t}=\phi_{f} \phi_{s y s} \phi_{c o n}\left(\frac{2 f_{r}}{\lambda}\right)=\frac{2 \psi f_{r}}{\lambda} \\
\Rightarrow P_{u l t}=V_{u l t} L=\frac{2 \psi f_{r} L}{\lambda}
\end{gathered}
$$

where $P_{u l t}$ and $V_{u l t}$ are the ultimate shear strength and ultimate shear strength per unit length of the wall, respectively, and $\psi=$ $\phi_{f} \phi_{\text {sys }} \phi_{\text {con }}$.

where $\phi_{f}, \phi_{s y s}$ and $\phi_{c o n}$ are factors related to the type of stopping/setting or finishing in the joints, the type of partition wall system, and the type of gypsum plasterboard-to-frame connection, respectively.

The approximate values of these factors are obtained directly from the experimental results by comparing the ultimate shear strengths of similar wall configurations, with different details, available in the literature.

For example:

1. $\phi_{s y s}$ in partitions with the return walls is taken as 2.0 according to the experimental results provided in [45].

2. $\phi_{\text {sys }}$ in partitions with steel framing is taken as 0.88 , which is obtained by dividing the ultimate strength of the wall with steel frame by the ultimate strength of the wall with wood frame, having similar details from Table 3 in [47] i.e., $\phi_{\text {sys }}=11.7 / 13.2=0.88$.

These values are shown in Table 2 .

\section{Displacement Analysis}

A lateral displacement equal to the cumulative vertical gap

\begin{tabular}{|c|c|c|}
\hline \multicolumn{3}{|c|}{$\phi_{s y s}$} \\
\hline Author & $\begin{array}{c}\text { Type of rigid wall } \\
\text { system }\end{array}$ & $\phi_{\text {sys }}$ \\
\hline- & $\begin{array}{c}\text { Timber frame } \\
\text { without return walls } \\
\text { (Isolated/Planar } \\
\text { Wall) }\end{array}$ & 1.0 \\
\hline $\begin{array}{c}\text { Liew et al., } 2002 \\
{[45]}\end{array}$ & With return walls & 2.0 \\
\hline $\begin{array}{l}\text { Swensen et al., } \\
2015 \text { [47] }\end{array}$ & Steel frame & 0.88 \\
\hline $\begin{array}{c}\text { Restrepo and } \\
\text { Befrosky, } 2011 \\
{[49]}\end{array}$ & $\begin{array}{l}\text { Steel frame with the } \\
\text { vertical slotted top } \\
\text { track }\end{array}$ & 0.65 \\
\hline \multicolumn{3}{|c|}{$\phi_{c o n}$} \\
\hline Author & Type of connection & $\phi_{c o n}$ \\
\hline- & Screws only & 1.0 \\
\hline $\begin{array}{c}\text { Olivia, } 1990 \\
\text { [36], and } \\
\text { Filiatrault and } \\
\text { Foschi, } 1991 \\
\text { [62] }\end{array}$ & $\begin{array}{l}\text { Screw or nail and } \\
\text { construction } \\
\text { adhesive }\end{array}$ & 1.6 \\
\hline \multicolumn{3}{|c|}{$\phi_{f}$} \\
\hline Author & Type of finishing & $\phi_{f}$ \\
\hline- & Unfinished joint & 1.0 \\
\hline $\begin{array}{c}\text { Memari et al., } \\
2009 \text { [63] }\end{array}$ & $\begin{array}{l}\text { Mesh joint tape and } \\
\text { joint compound }\end{array}$ & 1.5 \\
\hline
\end{tabular}
width $\Delta_{\text {vgap }}$ can be accommodated before the plasterboards and
Table 2: Approximate values of the $\phi$ factors.

their connections fully engage to provide additional lateral stiffness/resistance in walls with friction-sliding systems comprising of vertical gaps along the vertical intermediate or boundary joints of the walls [18,43,64-66].

The displacement component due to rocking of steel-studs and plasterboard can be significant in walls with friction-sliding frame connections with some horizontal gap. The horizontal gaps may be present between the plasterboards or studs and the slabs. Such gap and sliding connections allow uplifting of walls without inducing any additional lateral strength/stiffness until the total horizontal gap width $\Delta_{\text {hgap }}$ is exhausted. In such cases, $\Delta_{R}$ is the top lateral displacement due to rocking of the wall, which can be calculated as:

$$
\Delta_{R}=\left(\frac{\Delta_{\text {hgap }}}{L}\right) \times H
$$

For displacement demands less than $\Delta_{v g a p}$ and $\Delta_{R}$, the stiffness of such partition wall systems with vertical or horizontal gaps can be considered negligible.

Equation 13, however, does not consider the displacement caused by potential buckling of the end studs of the wall observed in several steel-framed partition wall tests $[49,63]$. Restrepo and Bersofsky [49] states that the studs are significantly weaker than all the other parts of the wall, which in turn can give rise to a high frequency of screw damage in steel-framed walls.

Moreover, when the opposite corners of the plasterboard coincide with the adjacent corners of the structural frame (or other 
boundary elements) at the end of the rocking motion, the plasterboard starts being subjected to diagonal compressive forces. At this stage, the engaged corners of the gypsum plasterboard are more likely to get crushed due to concentrated loads and possible impacts. Subsequently, the plasterboard tends to buckle in the out-of-plane direction accompanied by shortening in the loaded direction similar to that in glazed windows [67]. This mechanism is disregarded by equation 7 , which assumes that the plasterboards have adequate stiffness so that the out-of-plane panel deformation can be ignored: this assumption may hold true in cases when the screws are used in conjunction with adhesives as it tends to make the failure mode more brittle [61]. The diagonal shortening continues until the plasterboard fails at its flexural tensile strength in a diagonal buckling failure mode. Sucuoğlu and Vallabhan [67] approximate the resulting lateral drift $\theta_{b k}$ corresponding to lateral displacement of $\Delta_{b k}$ due to this mechanism as:

$$
\theta_{b k}=\frac{1}{b h}\left(\frac{\sigma_{f} d^{2}}{\pi E t}\right)^{2}
$$

where $b$ is the length of the wall or each plasterboard when the plaster-joint between the plasterboards is assumed to remain intact or damaged before buckling, respectively, $h$ is the height of the wall, and $d$ is the diagonal length of the wall $\left(d=\sqrt{b^{2}+h^{2}}\right)$. Moreover, $\sigma_{f}, E$ and $t$ are the modulus of rigidity or flexural strength $(\approx 4 \mathrm{MPa}[26,57])$, elastic modulus $(\approx 2000 \mathrm{MPa}[26,57])$ and thickness of gypsum plasterboard, respectively.

Incorporating these different displacement components in equation 4 gives a general equation for the total displacement as:

$$
\Delta_{t}=\Delta_{f}+\Delta_{s}+\Delta_{s s}+\Delta_{r k}+\Delta_{R}+\Delta_{\text {vgap }}+\Delta_{b k}
$$

Initially, the displacement components corresponding to the flexural deformation of the internal frame, racking behaviour, rocking due to horizontal and vertical seismic reliefs, and buckling of plasterboard can be considered negligible (i.e, $\Delta_{f}, \Delta_{r k}, \Delta_{R}$, $\Delta_{v g a p}$, and $\Delta_{b k} \rightarrow 0$ ) in rigid partition walls with adequate holddown capacity. Thus, equation 15 is simplified as:

$$
\Rightarrow \Delta_{t}=\Delta_{s}+\Delta_{s s}=\left[\frac{H}{G L t}+\frac{2 d_{s o}}{n_{h} f_{r}}\left(1+\frac{H}{L}\right)\right] P
$$

The predicted load vs. displacement $\left(\Delta_{S}+\Delta_{s s}\right)$ curves using equation 16 are plotted in Figure 4 for four wall specimens tested by McCutcheon [68]. The parameters considered here are $d_{s o}=3 \mathrm{~mm}$ and $f_{r}=1226 \mathrm{~N} \mathrm{[68]}$.

In Figure 4, it can be observed that the line connecting the origin with the ultimate displacement given by equation 16 can reasonably estimate the equivalent elastic stiffness (specially in Figure 4a), whereas it consistently underestimates the racking displacements at higher load levels in all cases. Hence, this equation cannot be relied to predict the lateral in-plane response of partition walls.

Given, the ultimate strength and initial stiffness of a partition wall by equation 12 and equation 10 , respectively, the interstory drift at which the ultimate strength is achieved $\theta_{u l t}$ can be obtained as:

$$
\theta_{u l t}=\frac{P_{u l t}}{K_{e q} H}
$$

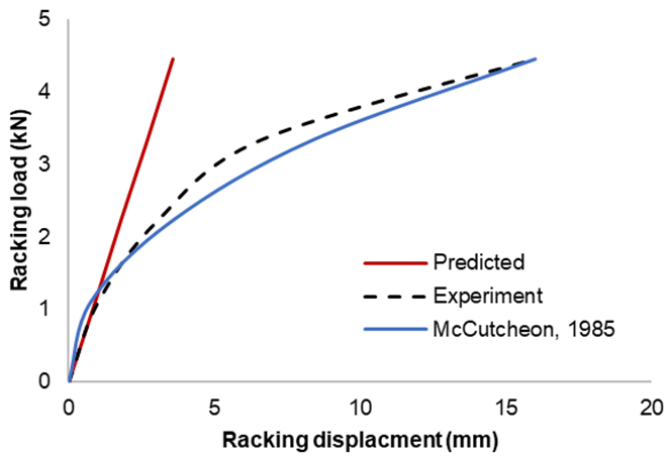

(a) $8 \mathrm{ft}(2440 \mathrm{~mm})$ by $8 \mathrm{ft}(2400 \mathrm{~mm})$ wall with 8 in (203mm) screw spacing, two $4 \mathrm{ft}(1220 \mathrm{~mm})$ long sheets.

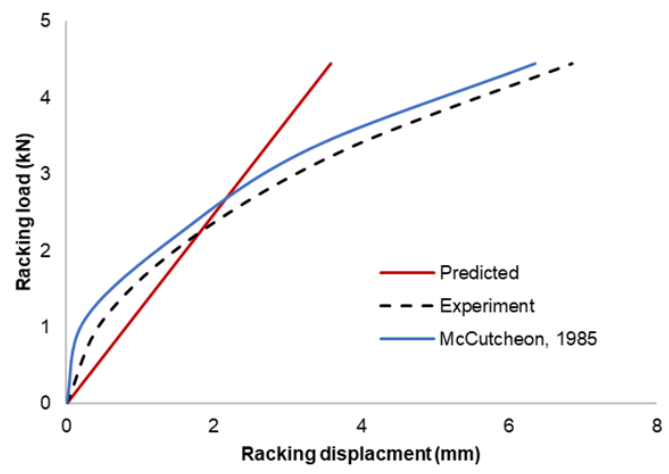

(b) $8 \mathrm{ft}(2440 \mathrm{~mm})$ by $8 \mathrm{ft}(2400 \mathrm{~mm})$ wall with 8 in (203mm) screw spacing, one $8 f t(2440 \mathrm{~mm})$ long sheet.

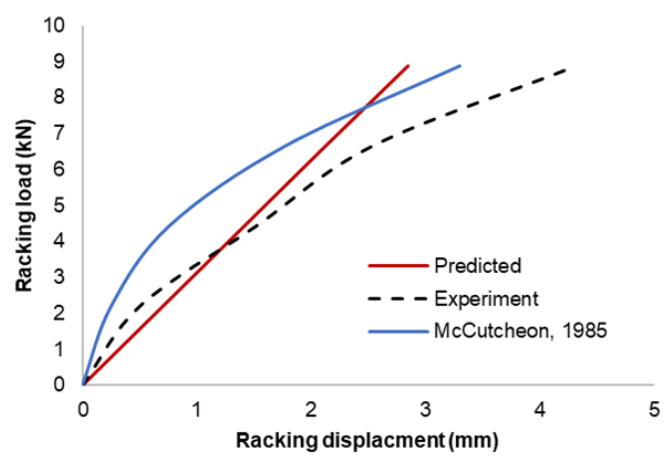

(c) $8 \mathrm{ft}(2440 \mathrm{~mm})$ by $16 \mathrm{ft}(4880 \mathrm{~mm})$ wall with $8 \mathrm{in}$. $(203 \mathrm{~mm})$ screw spacing, one $16 \mathrm{ft}(4880 \mathrm{~mm})$ long sheet.

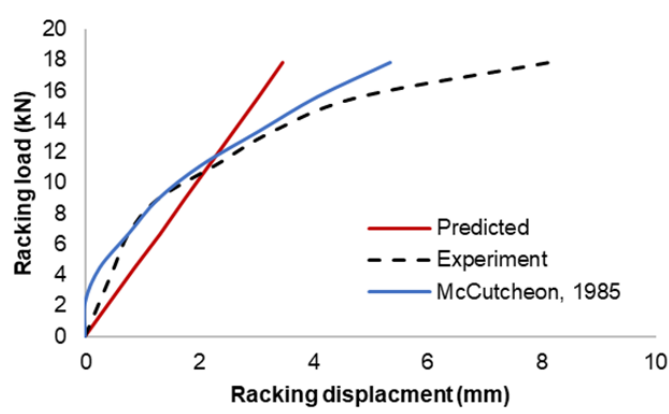

(d) $8 \mathrm{ft}(2440 \mathrm{~mm})$ by $24 \mathrm{ft}(7315 \mathrm{~mm})$ wall with $8 \mathrm{in}$. (203 mm) screw spacing, one $24 \mathrm{ft}(7315 \mathrm{~mm})$ long sheet.

Figure 4: Load-displacement curves for walls [68]. proximated as:

$$
\theta_{f r}=\frac{V_{f r} L}{K_{e q} H}
$$


The accuracy of equation 18 in predicting the onset drift for screw failure is assessed by comparing with the experimental drifts corresponding to screw failures of different types of rigid partition walls, available in the literature, as shown in Table 3. It can be observed that these values are in a reasonable agreement. The probable reason for some variations may be the property of the setting applied over the screw head to conceal the damage to the screws [63], screws being overdriven [57], or the selection of the values of $d_{s o}$ and $f_{r}$.

Table 3: Comparison between theoretical and experimental on-set drifts for screw-failure.

\begin{tabular}{cccc}
\hline \multirow{2}{*}{ Author } & Frame type & \multicolumn{2}{c}{ Onset inter-story drift $(\%)$} \\
\cline { 3 - 4 } & & Theoretical & Experimental \\
\hline $\begin{array}{c}\text { Tasligedik, } \\
\text { 2014 [43] }\end{array}$ & Timber & 0.21 & 0.30 \\
$\begin{array}{c}\text { McMullin et } \\
\text { al., 2007 } \\
\text { [69] }\end{array}$ & Timber & 0.19 & 0.30 \\
$\begin{array}{c}\text { Amer et al., } \\
\text { 2016 [50] }\end{array}$ & Steel & 1.00 & 0.78 \\
$\begin{array}{c}\text { Pali et al., } \\
\text { 2018 [65] }\end{array}$ & Steel & 1.17 & 0.96 \\
\end{tabular}

\section{Prediction of Bilinear Backbone Curves}

Assuming symmetrical behaviour of a partition wall under lateral loads interconnecting the points: $A\left(-\theta_{b k}, 0\right), B\left(-\theta_{u l t},-P_{u l t}\right)$, $C(0,0), D\left(\theta_{u l t}, P_{u l t}\right)$ and $E\left(\theta_{b k}, 0\right)$ form a bilinear backbone curve (see Figure 5). Here, $\theta_{b k}$ is assumed to be the drift, which represents the very extreme damage state of partition walls at which the wall's capacity theoretically reaches zero. The line BA and $\mathrm{DE}$ are represented as lines with a negative slope indicating progressive damage occurring to the partition wall at increasing drift levels; instead of a straight line suddenly dropping to zero at $\mathrm{A}$ and $\mathrm{E}$ when $\theta_{b k}$ is reached. The predicted and experimental backbone curves (redrawn as bilinear curves) of several partition walls found in the literature $[50,63]$ are shown in Figure 5. It can be observed that the predicted curves can reasonably approximate the experimental bilinear backbone curves.

In reality, there will always be some residual capacity at the buckling drift of $\theta_{b k}$ (as seen in the experimental response), which is not captured by the simplified prediction adopted herein. Nevertheless, the predicted failure (i.e. buckling) drift corresponding to zero capacity is normally greater than the experimentally measured buckling drift, which reduces the effect of ignoring the residual capacity in the post-peak response until the experimental buckling drift. For example, in Figure $5 \mathrm{c}$ the experimental curve terminates (i.e. fails) at $2 \%$ drift because of severe buckling of the steel end-studs, but the predicted response continues until beyond $4 \%$ drift. Consequentially, despite ignoring residual capacity at buckling failure, the predicted response gives higher strength at the experimental failure point (i.e. $2 \%$ drift). The predicted response at higher levels of drift (not backed up by experimental response) is inconsequential as the drifts are greater than the maximum inter-storey drift expected at the ultimate limit state (e.g. $2.50 \%$ in NZ standards).

\section{CAPACITY BASED DESIGN FOR SCREW SPACING}

In horizontally oriented plasterboards, shear strength of the plastered joint between the plasterboards can be taken as equal to that of the shear strengths of the screws present along both sides

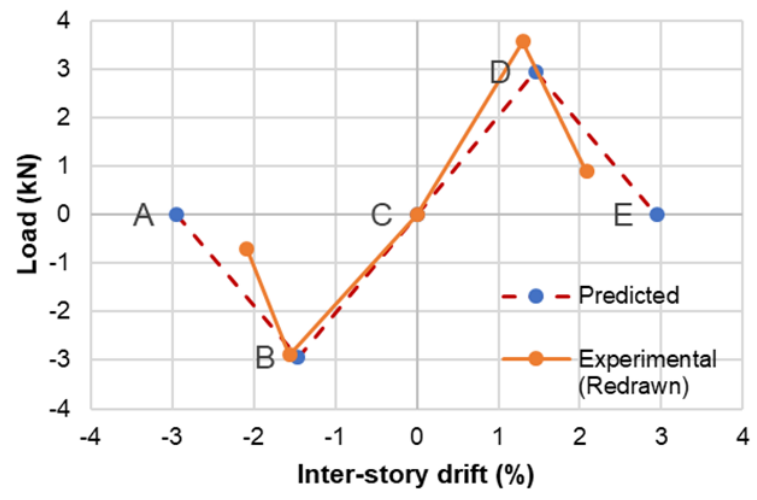

(a) Specimen NDS from Amer et.al., 2016 [50].

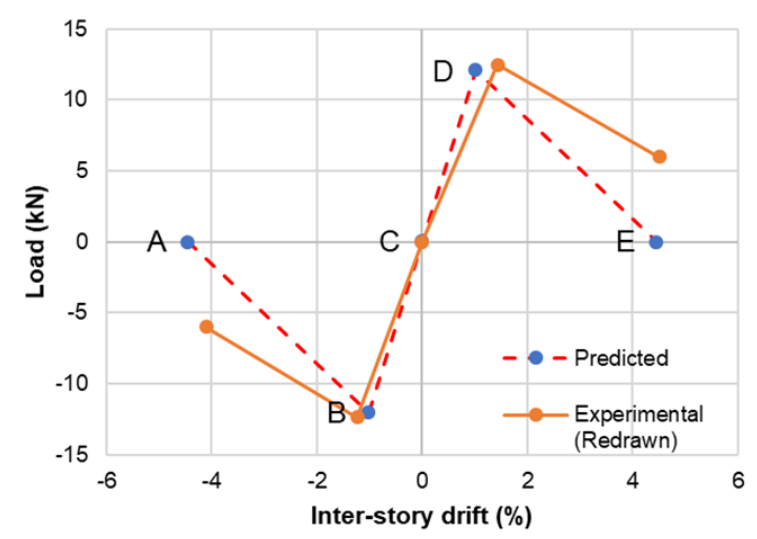

(b) Specimen WSC1 from Memari et al., 2009 [63].

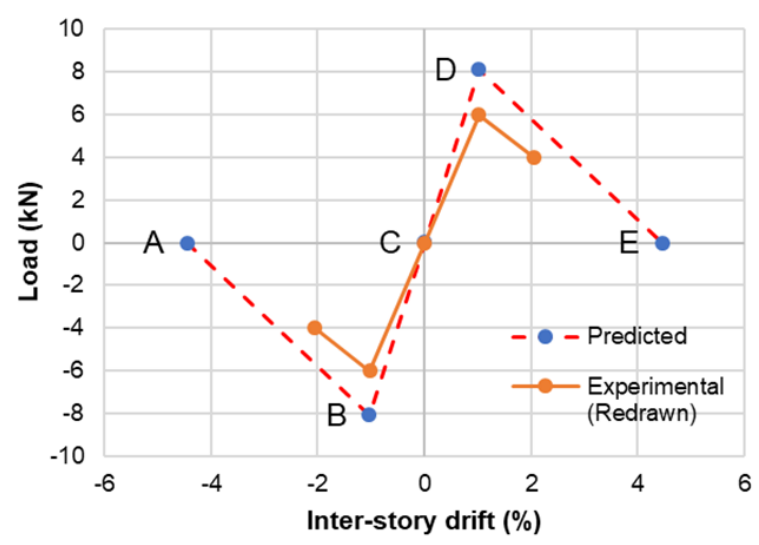

(c) Specimen MSC1 from Memari et al., 2009 [63].

Figure 5: Comparison between predicted and experimental backbone curves (redrawn as bilinear curves).

of the joint of the wall, as shown in Figure 6. For one of the plasterboards,

$$
\frac{P_{p s}}{2}=\left(\frac{L}{X_{s s}}\right) f_{r}
$$

where $L$ is the length of the wall, $f_{r}$ is the shear-strength of each screw connection between the plasterboard-and-internal stud, and $X_{S S}$ is the screw spacing along each side of the plastered joint (or equal to the spacing of the studs when screws are driven only to the studs).

The shear strength of the plastered joint $P_{p s}$ is given by $P_{p s}=$ $p_{s} R_{p}$, where $p_{s}$ and $R_{p}$ are the shear strength per unit length (shown in Table 4) and the total length of the plastered joint, respectively. For horizontal joints along the length of the wall, 


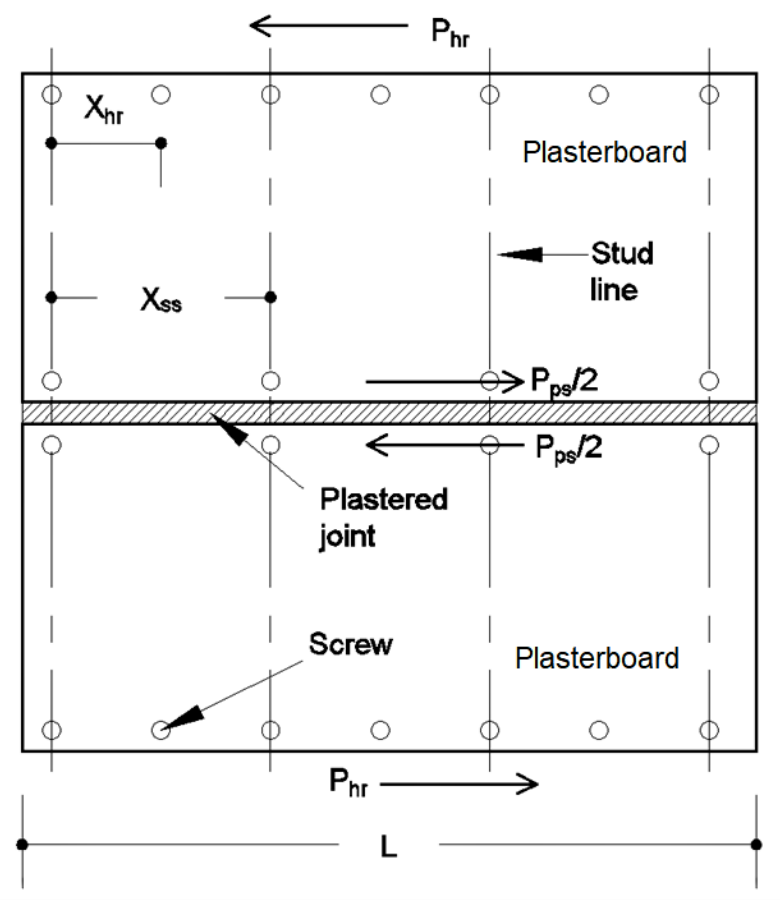

Figure 6: Schematic diagram of force transfer mechanism through plastered joint in horizontally oriented plasterboards.

$R_{p}$ can be taken equal to the length of the wall $L$. Substituting these in equation 19 ,

$$
\begin{gathered}
\Rightarrow \frac{p_{s} L}{2}=\left(\frac{L}{X_{s s}}\right) f_{r} \\
\Rightarrow X_{s s}=\frac{2 f_{r}}{p_{s}}
\end{gathered}
$$

Table 4: Shear strength of typical plastered joints.

\begin{tabular}{cc}
\hline Type of joint & $\mathbf{p}_{\mathbf{s}}(\mathbf{k N} / \mathbf{m})$ \\
\hline $\begin{array}{c}\text { Perforated paper-tape with three } \\
\text { coats of cement joint [44,58] }\end{array}$ & 7.2 to 8.0 \\
Fibreglass tape joint [44] & 5.9 \\
$\begin{array}{c}\text { Paper-tape filled with two coats of } \\
\text { bedding compound [26] }\end{array}$ & 2.0 to $2.5^{*}$ \\
Back-blocked joint (a strip of \\
gypsum plasterboard adhered \\
behind the joint using GIB @ Cove \\
adhesive [26]
\end{tabular}

*These values are indicative only.

For a standard case with $f_{r}=0.5 \mathrm{kN}$, and $p_{s}=2.5 \mathrm{kN} / \mathrm{m}$, we obtain $X_{S S}=400 \mathrm{~mm}$. Generally, at the boundaries, the spacing of the screws is kept smaller than that in the field region i.e., $X_{h r}<X_{s s}$.

Similarly, if the plasterboards are oriented vertically then,

$$
X_{v r}=\frac{2 f_{r}}{p_{s}}
$$

where $X_{v r}$ is the required vertical spacing of the screws.

If the vertical joints are provided along the stud line, it is easier to space the vertical screws required by equation 22 along both sides of the joint.
The cracking of the plastered joint before the screw failures may be desirable as the repair process for plaster cracks is generally easy and economical. Therefore, it may be prudent to conservatively provide screw spacing taken equal to or less than $X_{v r}$ along the boundaries.

\section{DETAILS OF TIMBER-FRAMED PARTITION WALL SPECIMEN}

A rigid timber-framed wall (TFW) specimen with details commonly used to construct interior partition walls in NZ buildings was constructed between two parallel concrete slabs supported by steel frames, as shown in Figure 7a.

The TFW specimen was tested to understand the inherent strengths and weaknesses in the current state of practice and to verify the above equations experimentally. The specimen tested was oriented oblique to the loading direction and had multiple short wing-walls with one ' $L$ '-junction (in the west) and one Y-junction (in the east), as shown in Figures $7 \mathrm{~b}$ and $7 \mathrm{c}$. It enabled examination of the bi-directional performance of walls under a unidirectional quasi-static cyclic loading. Moreover, assessment of the performance of walls with multiple orientations and junctions in a single test was possible. The specimen consisted of three types of walls (Planar Wall, Return Wall and Inclined Wall) as described in Table 5 and shown in Figure 7c.

Table 5: Wall-types and their geometry.

\begin{tabular}{ccccc}
\hline Wall-type & $\begin{array}{c}\text { Inclination } \\
\text { to the } \\
\text { loading } \\
\text { direction }\end{array}$ & $\begin{array}{c}\mathbf{L}^{*} \\
(\mathbf{m m})\end{array}$ & $\begin{array}{c}\mathbf{H}^{*} \\
(\mathbf{m m})\end{array}$ & $\begin{array}{c}\mathbf{t}^{*} \\
(\mathbf{m m})\end{array}$ \\
\hline $\begin{array}{c}\text { Planar wall } \\
(\mathrm{PW})\end{array}$ & $30^{\circ}$ & 2410 & 2405 & 116 \\
$\begin{array}{c}\text { Return wall } \\
\text { at 'L' (RW } \mathrm{L}) \\
\text { and 'Y' } \\
\text { junction } \\
\text { (RW }\end{array}$ & $60^{\circ}$ & 600 & 2405 & 116 \\
$\begin{array}{c}\text { Inclined wall } \\
\text { at ' } \mathrm{Y} \text { ' }\end{array}$ & $15^{\circ}$ & 605 & 2405 & 116 \\
junction \\
(IW
\end{tabular}

${ }^{*} L, H$ and $t$ are the length, height and thickness of the walls, respectively.

Following the typical practice in NZ, horizontal timber runners $(90 \mathrm{~mm} \times 45 \mathrm{~mm})$ were fastened to the concrete slabs (i.e., ceiling slab and floor slab) using anchor bolts (HILTI® HUS3$\mathrm{H} 8$ ) at spacings shown in Figure $7 \mathrm{c}$ during the construction of the specimen. Then, timber studs ( $90 \mathrm{~mm}$ x $45 \mathrm{~mm}$ ) were attached at a regular spacing of $600 \mathrm{~mm} \mathrm{c} / \mathrm{c}$ to these runners by driving 3 nails at an angle ( 2 from one side and 1 from the other). The vertical joint at the south of the Y-junction was reinforced with $135^{\circ}$ 0.55BMT (Base Metal Thickness) galvanized steel angles screwed to the studs. A single layer of $13 \mathrm{~mm}$ thick gypsum plasterboard was attached to the studs as well as runners using $\mathrm{GIB} \circledast$ grabber self-tapping drill point screws $(6 \mathrm{~g}$ × 25 $\mathrm{mm}$ ) on both sides of the walls. The spacing between the screws was kept at $300 \mathrm{~mm} \mathrm{c} / \mathrm{c}$ along the boundaries and in the field of the partition wall. Then, the joints were plastered with two coats of GIB ${ }^{\circledR}$ Tradeset 90 -minutes premium jointing compound, jointing tape and internal and external corner beads (/L-trims), where necessary. A final coat of plaster was applied with GIB ${ }^{\circledR}$ Trade Finish. Finally, after sanding the surface, two coats of paint 


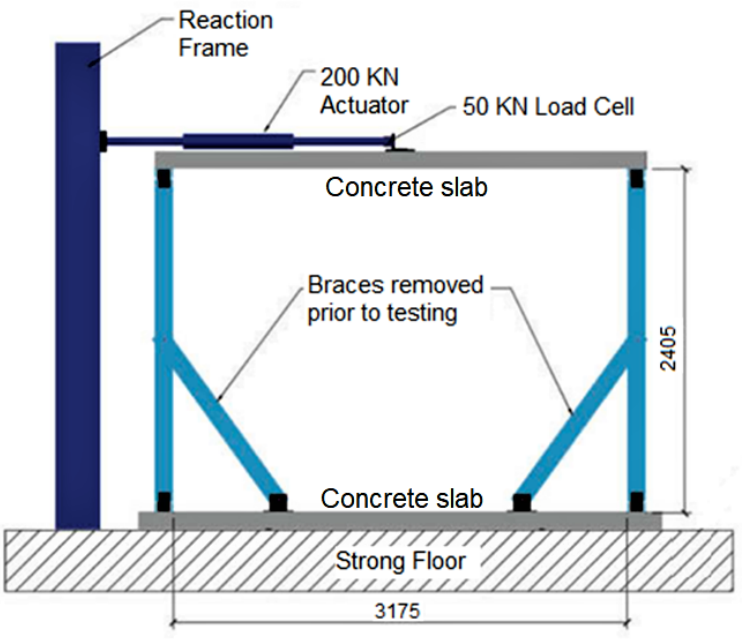

(a) Steel-frame structure-elevation [30].

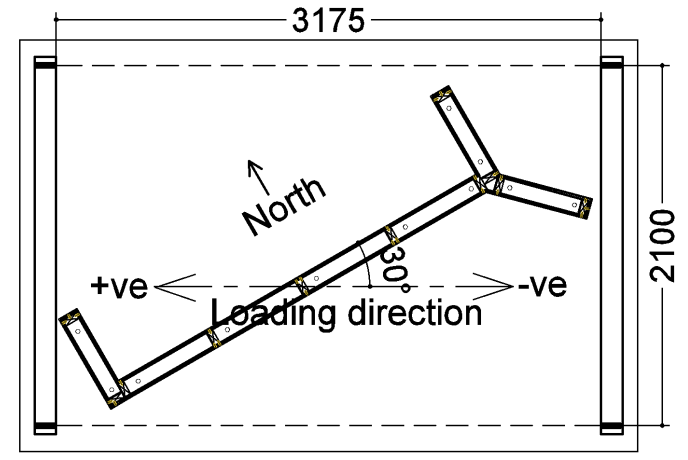

(b) Steel-frame structure with 'y' shaped TFW specimen-plan

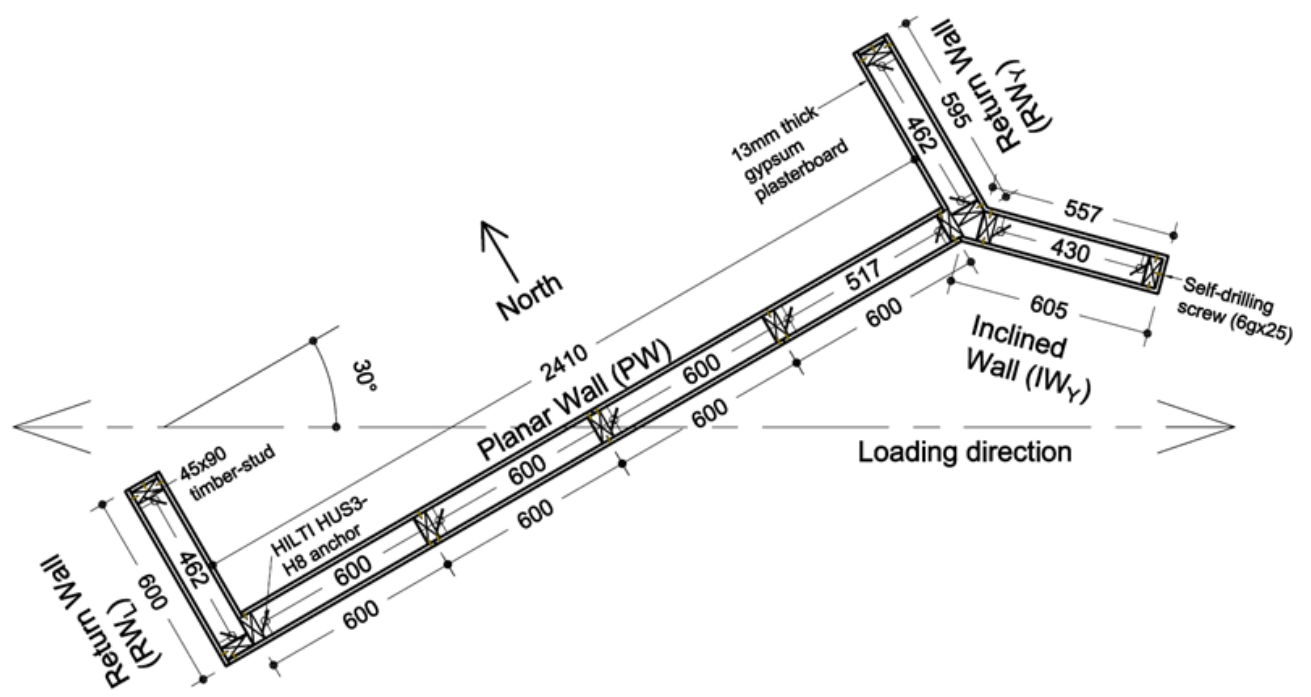

(c) Details of TFW specimen-plan.

Figure 7: Test setup and specimen details.

were applied on the wall surface before testing. The finished TFW specimen is shown in Figure 8.

\section{EXPERIMENTAL TEST OF THE PARTITION WALL}

\section{Test Setup, Loading Protocol and Data Acquisition}

The test frame, shown in Figure 7a, was hinged at the beamcolumn connections and at the bases of the columns to allow a shear mode of deformation under applied lateral cyclic displacements at the top of the frame. The top and bottom of the frame were connected to $120 \mathrm{~mm}$ thick reinforced concrete slabs with a clear height of $2405 \mathrm{~mm}$ between them. Further details on the test frame can be found in [30,31]. A $200 \mathrm{kN}$ actuator supported by a reaction frame was attached to the centre of the ceiling slab using bolt connections. The load applied to the specimen was recorded with a $50 \mathrm{kN}$ load cell with an accuracy of \pm 3 $\mathrm{N}$. The specimen was subjected to a displacement-controlled unidirectional quasi-static cyclic protocol defined in FEMA 461 [70], as shown in Figure 9.

Two cycles were applied at each drift amplitude where the drift amplitude of each step was 1.4 times the amplitude of the preceding step. A total of 16 drift steps were applied, up to a maximum drift of $6.21 \%$ in the frame axis, which corresponds to a maximum in-plane and out-of-plane drifts of 5.38\% (more than twice of the allowable ultimate limit state of $2.50 \%$ drift) and $3.10 \%$, respectively, for the Planar Wall (PW). The response of the bare frame was approximately linear, with the stiffness of $10.1 \mathrm{~N} / \mathrm{mm}$, as shown in Figure 10. The specimen was instrumented with linear potentiometers to measure the vertical and out-of-plane displacements, as shown in Figure 11. The potentiometers recorded the relative linear displacement between the locations they were secured on the TFW specimen and the surface of the concrete slab. 


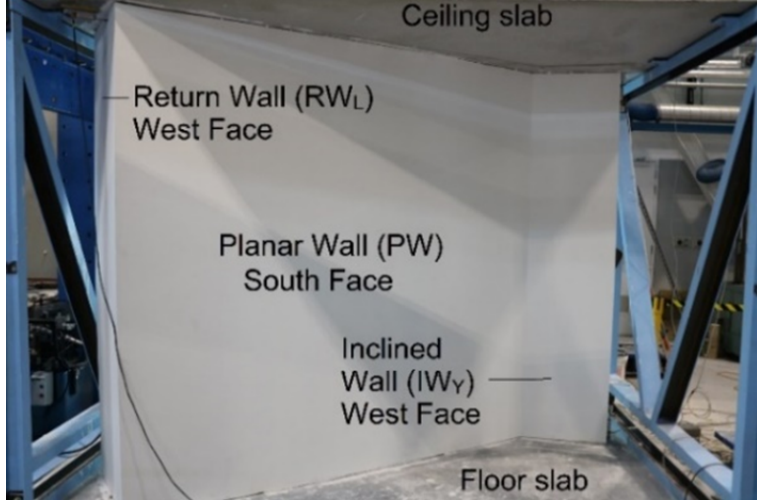

(a) South elevation

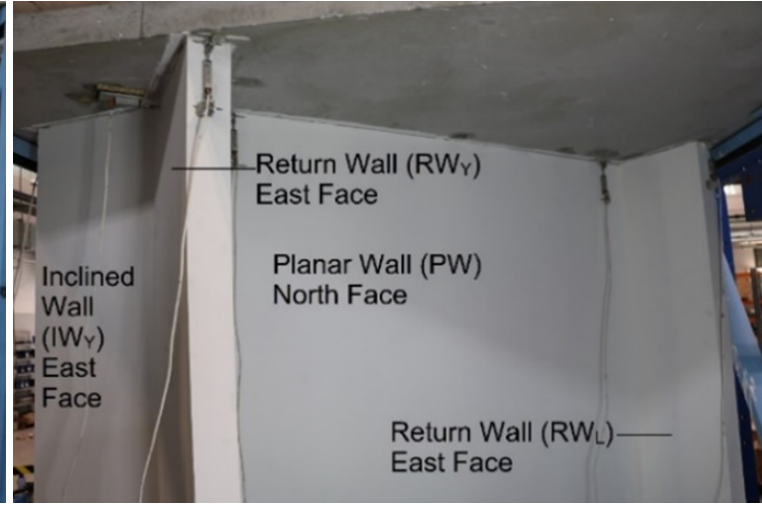

(b) North elevation.

Figure 8: Photos of the specimen prior to testing.

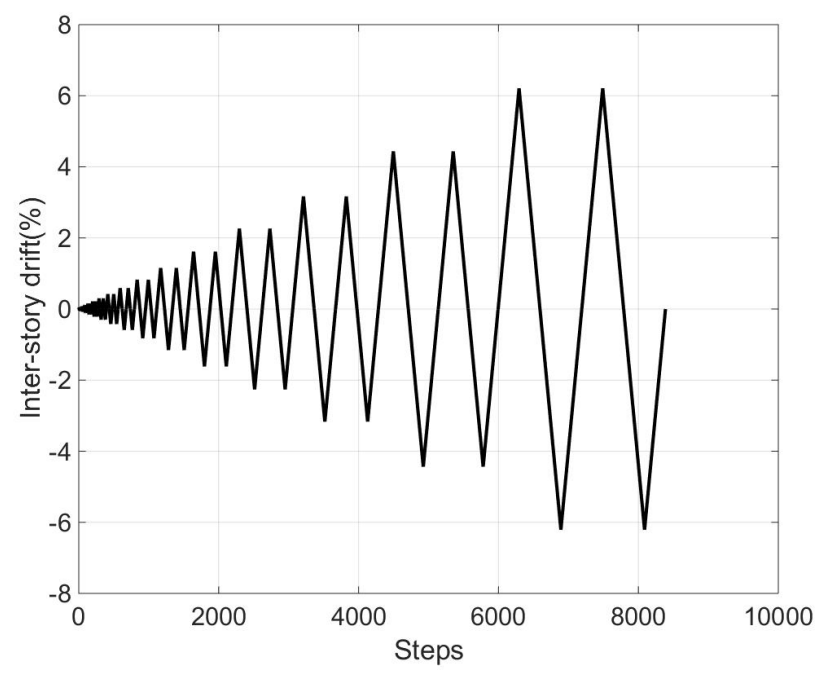

Figure 9: FEMA-461 loading protocol [70].

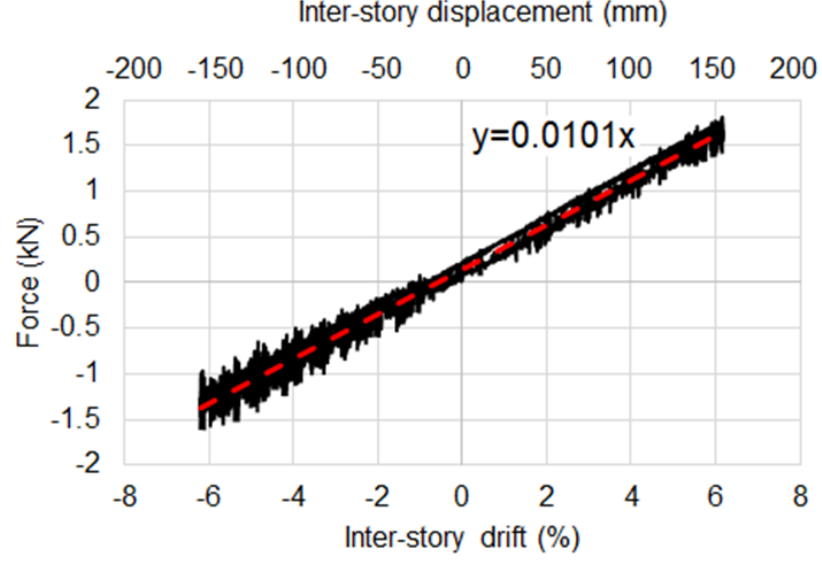

Figure 10: Force-displacement response of bare frame [30].
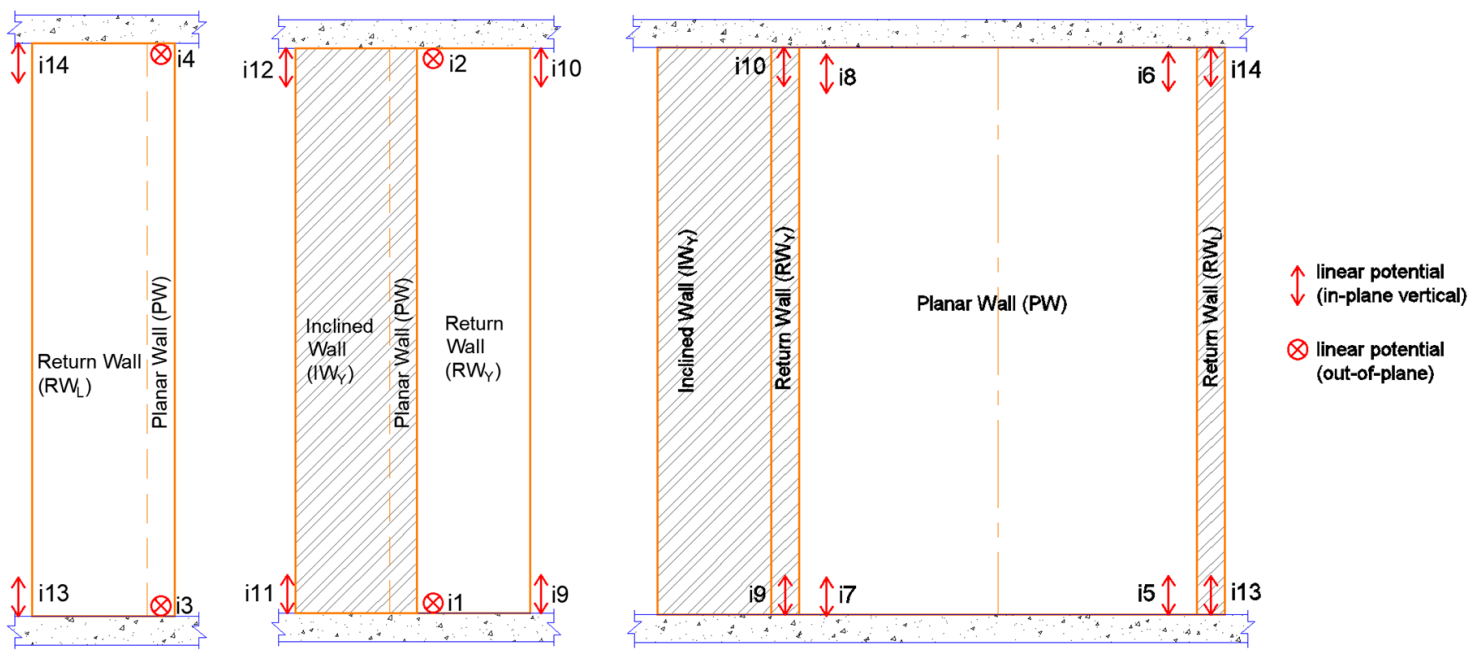

Figure 11: Instrumentation points: $R W_{L}$ West Face (left), Y-junction East Face (center) and PW North Face (right).

\section{Damage State Classifications}

The damage states for the characterization of the seismic performance of the TFW specimen are taken to be similar to those adopted by Mulligan et al. [30] so that a direct comparison with "partly-sliding" partition walls can be accomplished. The nature/extent of damage corresponding to these damage states is described in Table 6. Visual inspection of the specimen was done after each step of the applied FEMA 461 [70] loading protocol (Figure 9) and any damage observed was photographed and manually recorded. The observed damage during the experiment is shown in Figure 12.

Since the timber-frame was concealed behind the gypsum plasterboards, the exact drift at which the frame was damaged was not possible to be determined. The exposed frames where plas- 


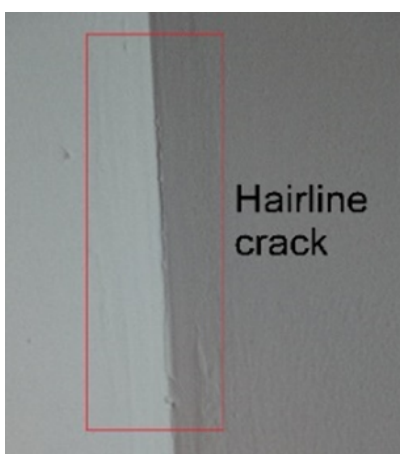

(a) Paint cracks (0).

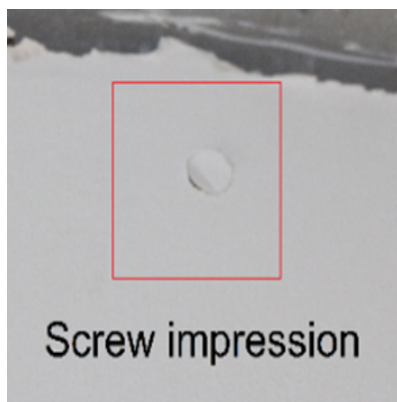

(d) Screw impressions (1b).

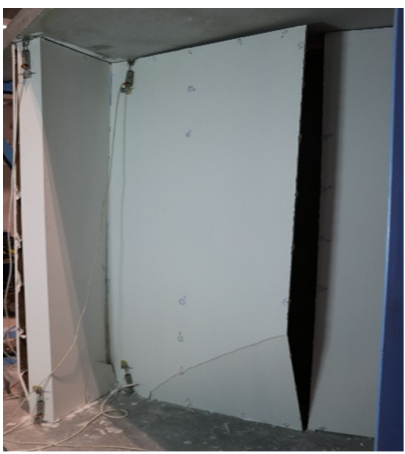

(g) Detachment between gypsum plasterboards and timber frame (2).

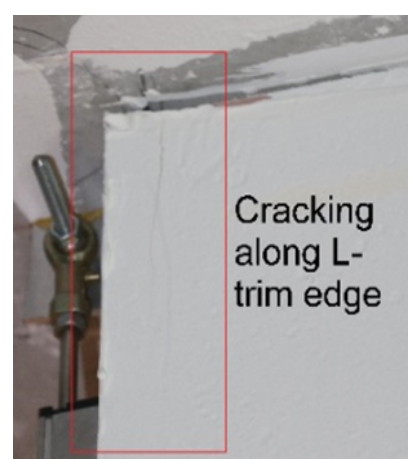

(b) Slight cracks along the edge (1a).

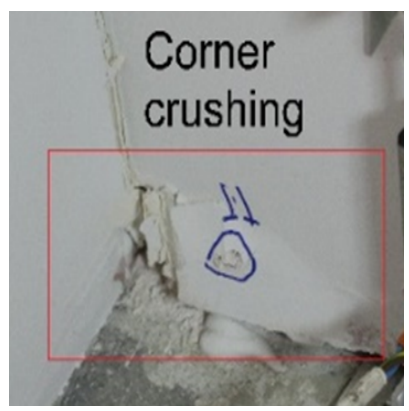

(e) Corner crushing (2).

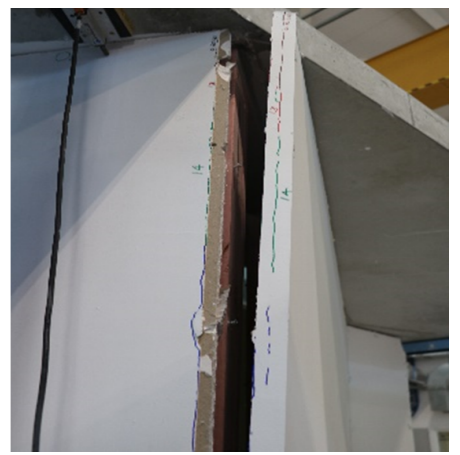

(h) Damage at stud and runner connection (2).

Cracking along internal corner juction

(c) Cracks along internal corner junction (1a).

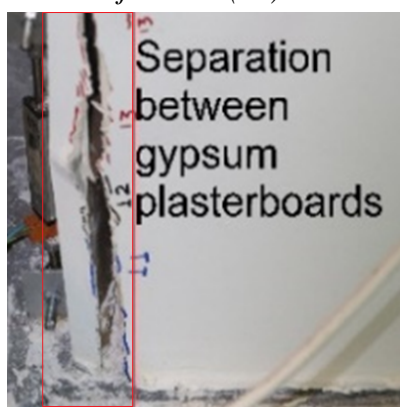

(f) Separation between adjacent gypsum plasterboards (2).

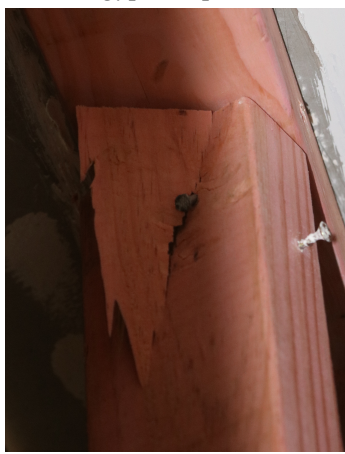

Figure 12: Examples of observed damage with damage states in brackets.

Table 6: Definition of different damage states and the required repair actions [30].

\begin{tabular}{|c|c|c|}
\hline Damage state & Description of associated damage & Required repair actions \\
\hline $\begin{array}{l}\text { DS0: Superficial damage to } \\
\text { lining interfaces }\end{array}$ & a) Paint cracks at the lining of joints & Barely visible not deemed to be repaired. \\
\hline \multirow{2}{*}{$\begin{array}{l}\text { DS1: Slight damage to } \\
\text { gypsum plasterboards }\end{array}$} & a) Cracks along the edge and corners & $\begin{array}{l}\text { Local repairs; putty knife to rout out the crack } \\
\text { or scarping of plaster or using paper-tape or } \\
\text { fiberglass tape along the crack, re-plastering } \\
\text { and re-painting rendering the repair concealed. }\end{array}$ \\
\hline & $\begin{array}{l}\text { b) Screw ridges/impressions on plasterboard } \\
\text { accompanied by cracks }\end{array}$ & $\begin{array}{l}\text { Re-tightening of the screws and placing } \\
\text { additional screws in the periphery followed by } \\
\text { re-plastering and re-painting }\end{array}$ \\
\hline $\begin{array}{l}\text { DS2: Distributed damage to } \\
\text { gypsum plasterboards }\end{array}$ & $\begin{array}{c}\text { Crushing of wall corners, Cracking of } \\
\text { plasterboards, Separation between adjacent } \\
\text { plasterboards, slight damage to the connection } \\
\text { between frame members }\end{array}$ & $\begin{array}{l}\text { Local repairs in the joints and edge-trims, local } \\
\text { removal and patching or replacement of } \\
\text { plasterboard, removal of bent nails and } \\
\text { re-nailing timber studs and runners }\end{array}$ \\
\hline $\begin{array}{l}\text { DS3: Detachment of gypsum } \\
\text { plasterboards and frame } \\
\text { damage }\end{array}$ & $\begin{array}{l}\text { Severe damage to both the plasterboards and } \\
\text { timber-frame }\end{array}$ & $\begin{array}{l}\text { Complete replacement of both plasterboards } \\
\text { and timber-frame; requires complete } \\
\text { demolition and replacement of wall. }\end{array}$ \\
\hline
\end{tabular}




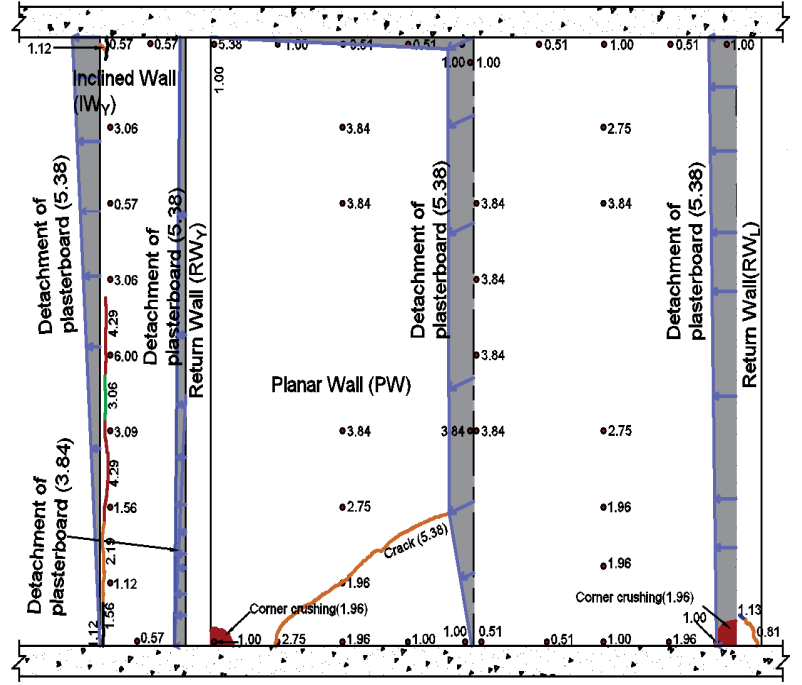

(a) PW North Face and IW $Y$ West Face.

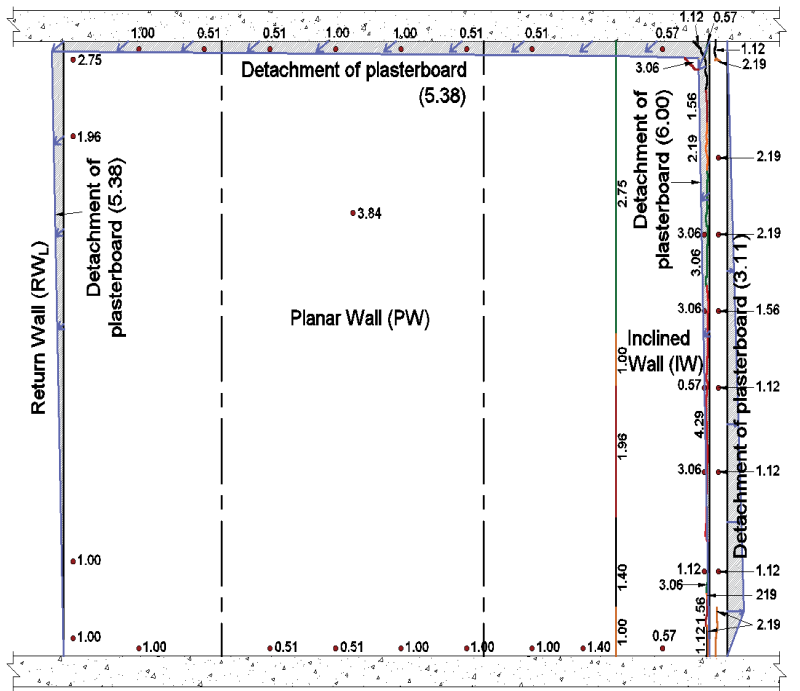

(d) PW South Face and IW $W_{Y}$ East Face.

$\begin{array}{ll}\text { - Screw } & \rightarrow \text { Direction of plasterboard } \\ \text { impressions/popping } & \text { detachment } \\ \text { Corner crushing } & \text { - Plasterboard joint } \\ \text { E Crack propagation } & \text { - Position of detached } \\ \text { lines } & \text { plasterboard }\end{array}$
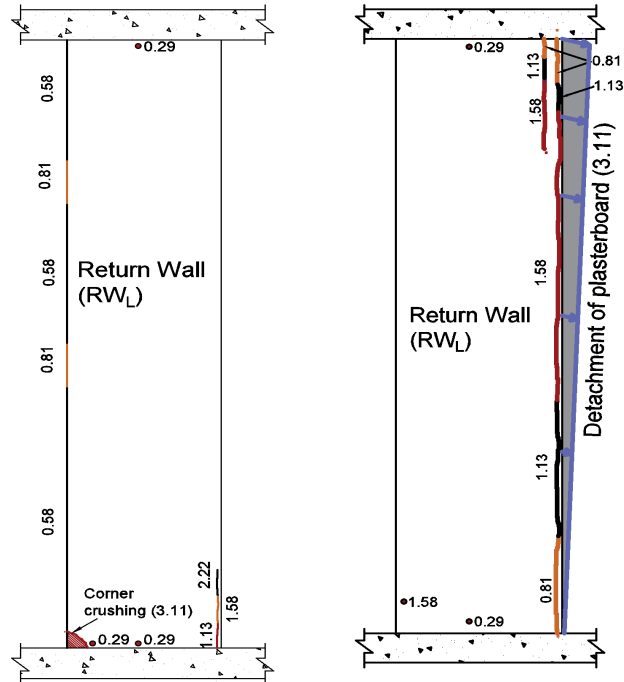

(b) $R W_{L}$ East Face.

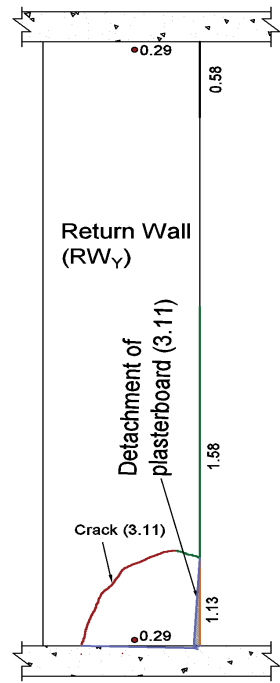

(e) $R W_{Y}$ West Face. (c) $R W_{L}$ West Face.

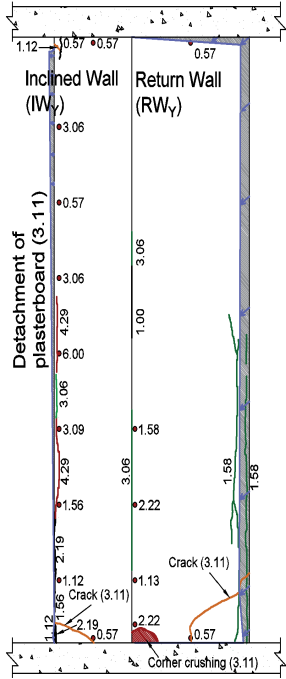

(f) Y-junction East Face.

\footnotetext{
$\square$ Regions where the timber-framing is exposed due to plasterboard detachment

$\square$ Damage at stud and runner joint
}

Figure 13: Schematic diagram of progression of damage with onset in-plane inter-story drifts for the walls.

terboards had detached could be inspected after the final cycle of the loading protocol was applied. Therefore, the values of drift corresponding to damage to connections between timber studs and runners, where provided, are the final maximum drifts applied to the specimen before the internal frame was inspected.

The inter-story drifts experienced by each wall type were different depending upon their orientation with the loading direction. The pictorial representation of the types of damage and their corresponding onset inter-story drifts associated with these wall types are shown in Figures 13 and 14.

\section{Force - Displacement Envelope}

Since the original force-drift data obtained from the experiment was noisy, the moving average for each force value was taken (with window size 3, which incorporated one value before and after the considered value) to smoothen the curve. The resulting force-drift hysteretic loops are shown in Figure 15. Figure 15 also shows the loading stage corresponding to the onset of different damage observed during the test as the load-displacement envelope curve in the linear elastic region is predicted by interconnecting the points: $A\left(-\theta_{b k}, 0\right), B\left(-\theta_{u l t},-P_{u l t}\right), C(0,0)$, $D\left(\theta_{u l t}, P_{u l t}\right)$ and $E\left(\theta_{b k}, 0\right)$ for this specimen.

The initial stiffness is generally provided by the plasterboard, stopped joints, and the screw connections between the plasterboards and the timber frame inside. After reaching the peak of each cycle, at the beginning of the unloading phase, the force rapidly decreased close to zero, which was then followed by a reduction of the displacement to zero with little change of the force. The specimen softened with each subsequent loading cycle, as indicated by the reduction of stiffness (more predominantly after the failure of the screws). Significant strength degradation can also be observed after the wall's ultimate strength is reached. This is in line with the typical behaviour of rigid-framed partition walls reported in other tests $[50,63]$ as well. 


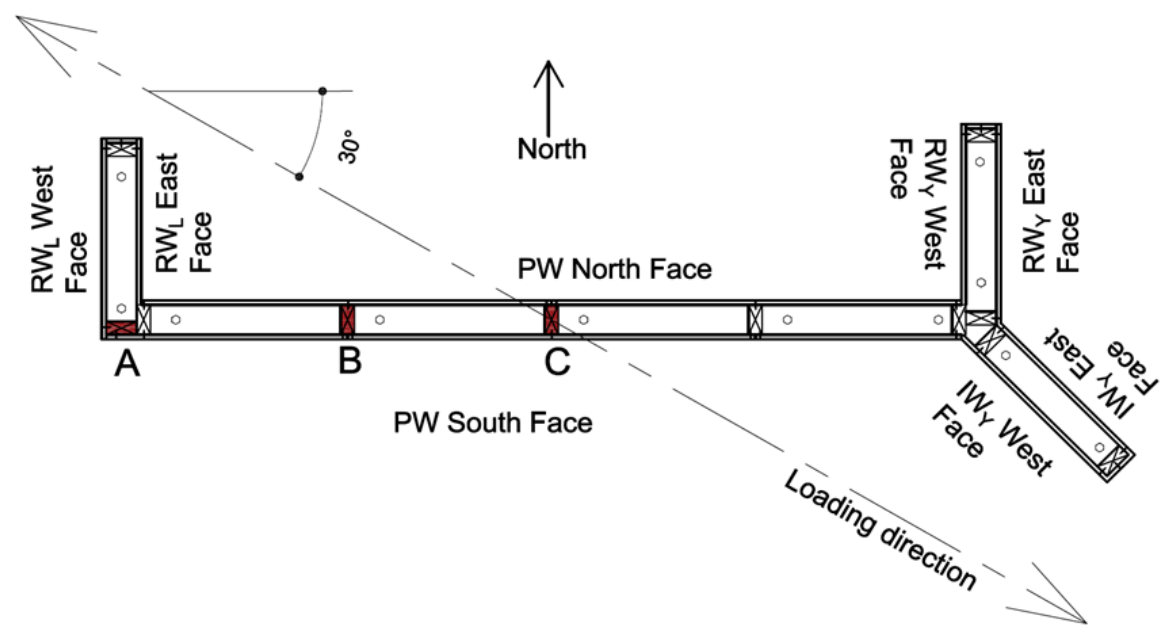

(a) Plan showing reference planes and locations of stud-to-runner connection damage (Legends as shown in Figure 13).

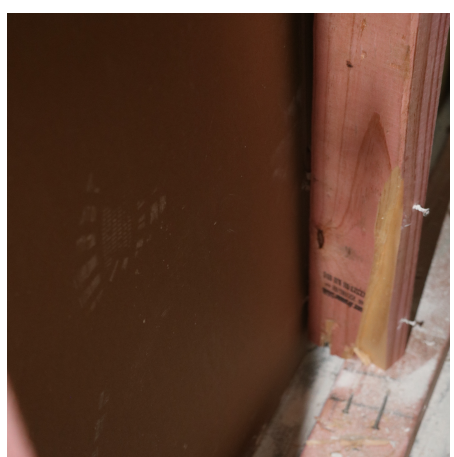

(b) Frame damage at $B$.

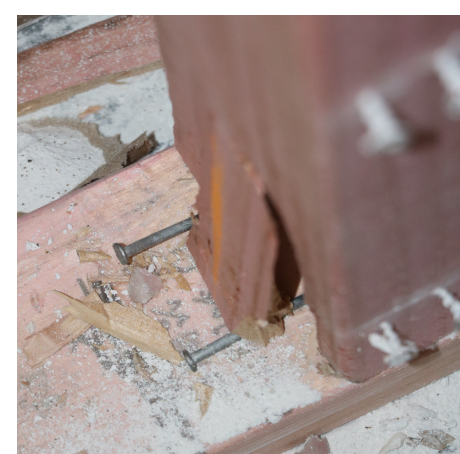

(c) Frame damage at $C$.

Figure 14: Damage observed to timber stud-and-runner connections visible through detached gypsum plasterboards.

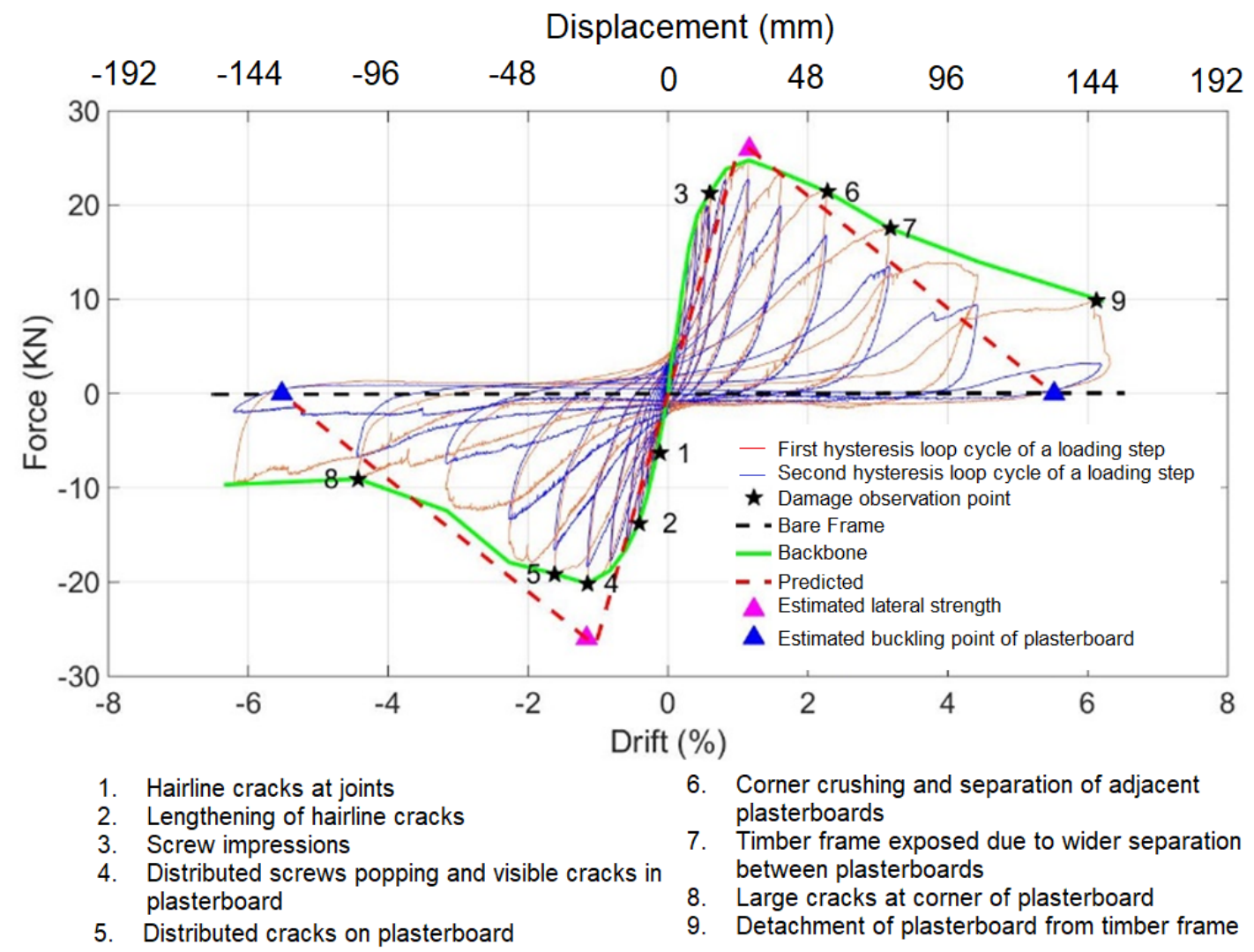

Figure 15: Hysteresis loop with damage points in the specimen. 


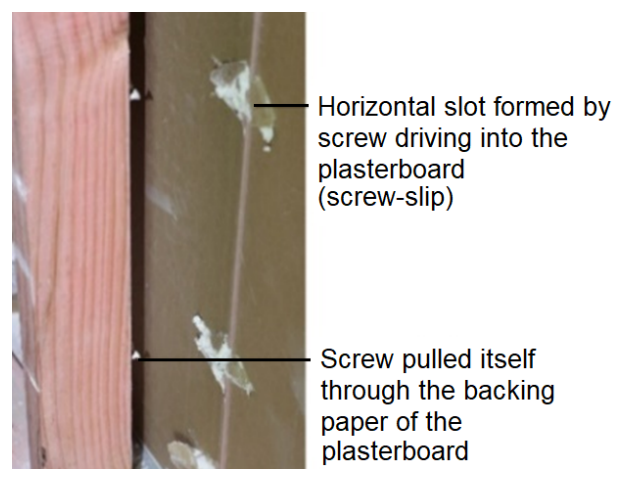

(a) Screws pulling through the backing paper of gypsum plasterboard.

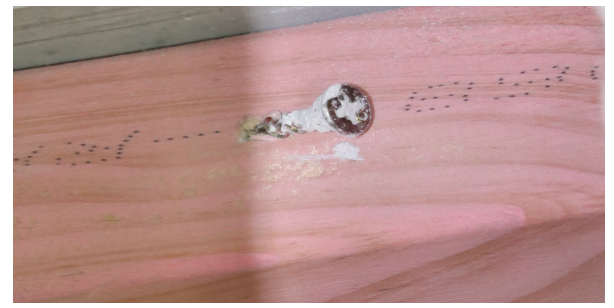

(c) Bent screw at top runner.

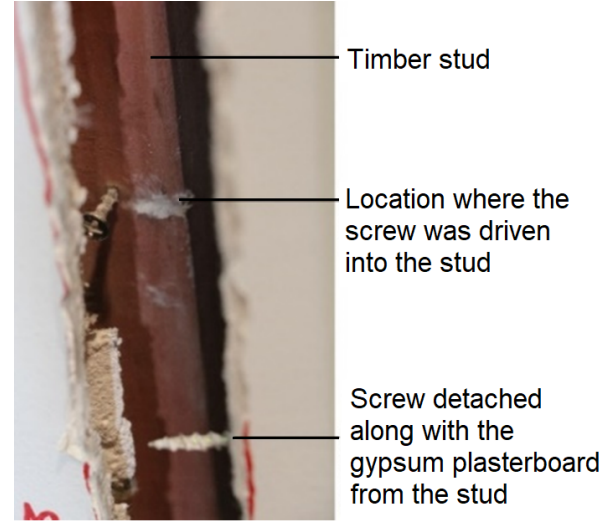

(b) Screw pulled by the gypsum plasterboard from the timber-stud.

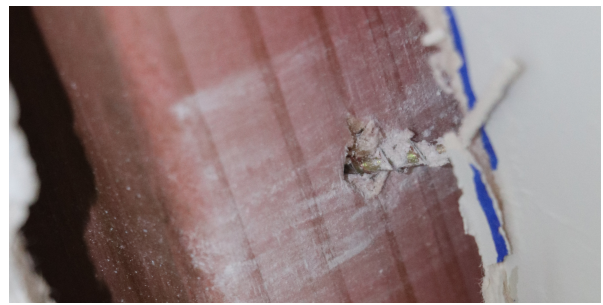

(d) Bent screw at an stud.

Figure 16: Bending and detachment of screws.

The ultimate shear load capacity for the TFW was found to be $24.80 \mathrm{kN} / 3.271 \mathrm{~m}=7.58 \mathrm{kN} / \mathrm{m}$ (where $3.271 \mathrm{~m}$ is the sum of the projected lengths of the wall segments in the loading direction). At the buckling drift of $\theta_{b k}$, the experimental curve still has a residual load, which is neglected by the predicted curve as $\theta_{b k}$ is theoretical to determine the strength degradation of the wall. As shown in Figure 15, the predicted point of screw failure lies close to the point of earliest screw failures (or impressions) in the experiment. This suggests that equation 18 can reasonably estimate the onset drift of screw failures. Furthermore, the assumption that $\theta_{b k}$ is the final damage state of the partition wall, immediately after which the lateral load drops down to zero, allows approximation of the post-peak response after the ultimate strength of the wall is reached.

\section{Propagation of Observed Damage and Hysteretic Response}

The gradual loss of strength and stiffness in the consecutive cycles can be attributed to: cracking in the joints and at the corners of the plasterboards, pulverization of the plasterboard around the screws, bending of screws, buckling of the plasterboard away from the timber-frame, and damage to the timber-frame. However, the timber-frame was found to sustain minor damage only at the stud and runner joints (Figures $14 \mathrm{a}-14 \mathrm{c}$ ) even at a very high in-plane drift of $5.38 \%$ corresponding to the Planar Wall. The damage to stud and runner connections is likely to have occurred before this drift as the studs try to uplift from the runners [58] during the racking motion of the wall; thereby causing bending moments and tension at the connections.

The first hairline crack (DS0) formed very early at an inter-story drift of $0.09 \%$ corresponding to the Planar Wall, between the Planar Wall of the specimen and the intersecting walls because the boundary walls $\left(\mathrm{RW}_{\mathrm{L}}, \mathrm{RW}_{\mathrm{Y}}\right.$ and $\left.\mathrm{IW}_{\mathrm{Y}}\right)$ tend to restrain the movement of the plasterboards relative to the timber-frame.

Numerous cases of screw impressions were perceived in the finished compound over the screw-heads, particularly at the top and bottom boundaries of the plasterboard after step $9(0.51 \%$ inter- story drift cycles corresponding to the Planar Wall) (Figures 12d and 13a). The screw impressions were found to propagate from the bottom boundary vertically towards the top boundary during the subsequent higher drift cycles (Figure 13a). The screws were believed to have started digging into the plasterboard during step 9 and gradually cutting through the plasterboard (Figure 16a) in the following cycles. The plasterboards may not have significantly displaced relative to the frame causing the stress to be distributed equally among the screw-connections.

This process formed slots in the plasterboards that contributed to the pinching behaviour under reversed cyclic loading. The screws, eventually, drew themselves out of the backing paper of the plasterboards. It allowed the plasterboards to further slip over the screws. Since the plasterboards were oriented vertically, the cut-edge may also have permitted the screws to tear through the paper at smaller forces. In a few cases, where the screws were driven very close to the edge of the timber studs the plasterboard was also able to pull some screws along with it (Figure 16b). In the South Face of the Planar Wall, the stopping over the screws kept the screw failures hidden as the horizontal slots were present on the inner surface of the gypsum plasterboard but were absent on the outer surface. Some screws were also bent (Figures 16c and 16d) in addition to cracking/crushing of timber around the periphery of screw connection (especially in cases where the screws were drilled quite close to the edge of the timber), contributing to the ductility and energy dissipation of the wall.

The cracks in plasterboards started around the periphery of corner beads, and subsequently, new cracks branched off the initial cracks (Figure 12b). There was a considerable increase in the extent of damage sustained by the plasterboards between $1.00 \%$ and $1.96 \%$ inter-story drift corresponding to the Planar Wall (Figure 13a).

Gypsum plasterboard has relatively low compressive and tensile strengths which can result in early onset of damage [57,71]. The corners of the gypsum plasterboards crushed, creating wrinkles 
Table 7: Parameters for the tested specimen.

Values of the parameters

\begin{tabular}{|c|c|c|c|}
\hline$X_{h}=300 \mathrm{~mm}$ & $X_{v}=300 \mathrm{~mm}$ & $d_{s o}=1 \mathrm{~mm}$ & $\phi_{\text {con }}=1.00$ \\
\hline$\phi_{f}=1.50$ & $f_{r}=0.50 k N$ & $\phi_{s y s}=2.00$ & $p_{s}=2.50 \mathrm{kN} / \mathrm{m}$ \\
\hline$\lambda=377.25$ & $L=2410 \mathrm{~mm}$ & $H=2405 \mathrm{~mm}$ & \\
\hline
\end{tabular}

Table 8: Comparison between experimental results and theoretical predictions for TFW specimen.

\begin{tabular}{|c|c|c|c|}
\hline Parameter & Theoretically predicted & Experimentally obtained & Percentage difference \\
\hline $\begin{array}{l}\text { Ultimate Shear strength per unit } \\
\text { length of the wall }\left(V_{u l t}\right)\end{array}$ & $7.95 \mathrm{kN} / \mathrm{m}$ & $7.58 \mathrm{kN} / \mathrm{m}$ & $4.88 \%$ \\
\hline Ultimate shear strength $\left(P_{u l t}\right)$ & $7.95 \times 3.271=26 \mathrm{kN}$ & $24.80 k N$ & $4.88 \%$ \\
\hline Equivalent lateral stiffness $\left(K_{e q}\right)$ & $0.93 \mathrm{kN} / \mathrm{mm}$ & $\begin{array}{c}1.72 \mathrm{kN} / \mathrm{mm} \text { (at } 75 \% \text { of the } \\
\text { ultimate load) }\end{array}$ & $45.9 \%$ \\
\hline Screw spacing $\left(X_{v r}\right)$ & $400 \mathrm{~mm}$ & $300 \mathrm{~mm}$ & $33.33 \%$ \\
\hline Screw failure onset drift $\left(\theta_{f r}\right)$ & $0.40 \%$ & $0.51 \%$ & $21.57 \%$ \\
\hline Plasterboard buckling $\operatorname{drift}\left(\theta_{b k}\right)$ & $5.53 \%$ & $5.38 \%$ & $2.78 \%$ \\
\hline
\end{tabular}

on the outer paper during smaller drift cycles followed by distributed cracks at larger drift cycles (Figure 12e). The ripping of the joint tapes and widening of cracks along the corner beads (Figures $12 \mathrm{f}$ and $12 \mathrm{~g}$ ) were indicative of relative movements between adjacent gypsum plasterboards.

While the specimen was able to sustain multiple displacement cycles beyond the peak response, the inelastic response was characterized by significant post-peak strength reduction and the specimen failed in a brittle manner during the final cycles. The plasterboards buckled diagonally in the out-of-plane direction and, ultimately, detached from the timber-frame. For the Planar Wall North face, the taped joints failed between the adjacent plasterboards and allowed for independent buckling of the plasterboards (Figure 12g). However, in the Planar Wall South face, the joint between the adjacent walls was found to be intact and both the plasterboards detached/buckled together away from the timber-frame. This indicates that the jointing compounds were strong enough to transfer the interface forces and allow the plasterboards to act as a rigid body.

The relative out-of-plane displacements between the top of the Ljunction and the top of Y-junction at the ends of the Planar Wall and the top slab are shown in Figure 17a. It can be observed that during initial cycles the deflections of the junctions at the two locations are comparable. However, with larger drift cycles, the Y-junction showed a tendency to deform in the positive direction and L-junction in the negative direction.

This can be attributed to the mechanism that the Planar Wall tries to restrict the motion of the Return Walls $\left(\mathrm{RW}_{\mathrm{L}}\right.$ and $\left.\mathrm{RW}_{\mathrm{Y}}\right)$ towards itself (and vice-versa), and gradual out-of-plane detachment of the instrumented gypsum plasterboard. During the final cycles of the test, the plasterboard detached from the frame at the junctions causing a sudden change in the potentiometer readings (with stroke capacity) at the top of the L-junction $\left(i_{4}\right)$ and Y-junction ( $\left.i_{2}\right)$ (Figure 11). Likewise, the relative out-of-plane displacements between the bottom of the L-junction and bottom of Y-junction at the ends of the Planar Wall, and the bottom slab are shown in Figure 17b.

The maximum shear force, initial stiffness, expected drifts for screw damage, and gypsum plasterboard buckling are calculated for the TFW specimen using the equations $12,10,18$, and 14,

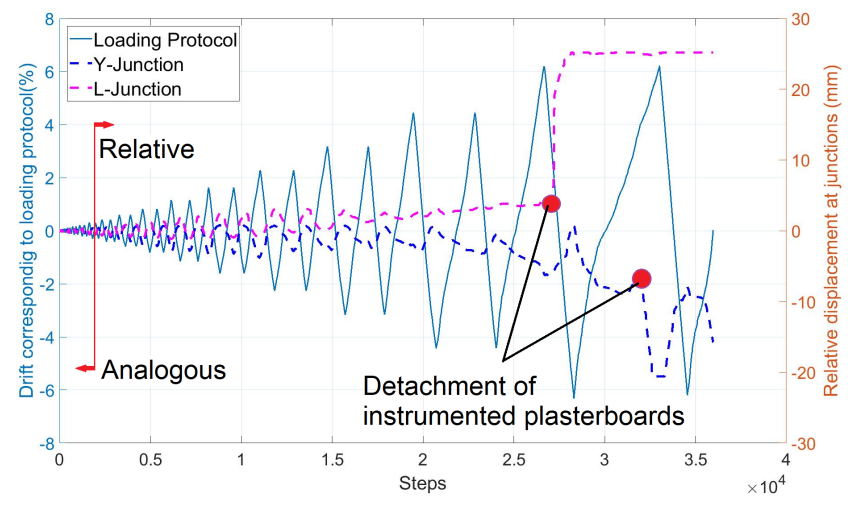

(a) At top of the junctions (at the ends of PW).

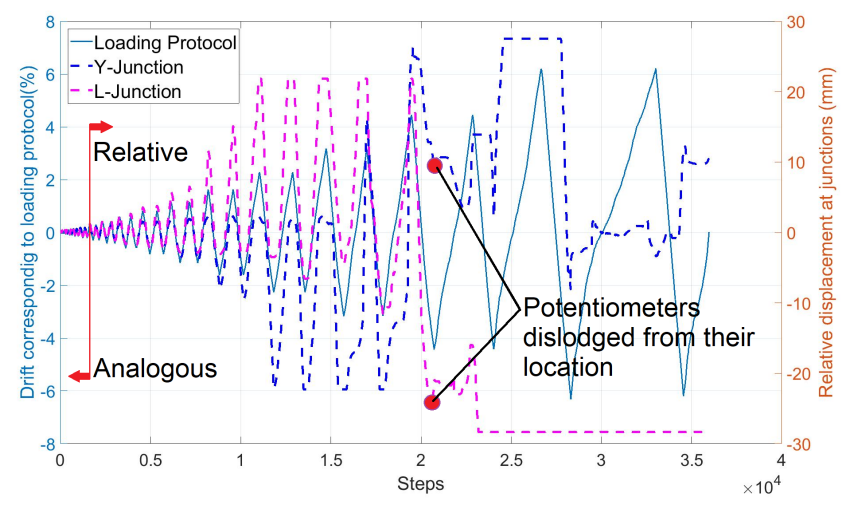

(b) At the bottom of the junctions (at the ends of PW).

Figure 17: The relative out-of-plane displacement of $L$ and $Y$ junctions to slabs.

respectively using the modification factors and parameters as shown in Table 7 for the analysis. These are compared with the experimental results, as shown in Table 8. It can be observed that the theoretical values are reasonably in agreement with the experimental results. Only the stiffness of the walls was underestimated, and this is thought to be due to the 3D nature of the wall specimen being neglected in stiffness estimation. 


\section{COMPARISON BETWEEN "PARTLY-SLIDING" STEEL-FRAMED AND RIGID TIMBER-FRAMED PARTITION WALLS}

The TFW specimen tested in this study had a similar configuration to the three "partly-sliding" internal steel-framed partition wall (PSW) specimens (A1, A2 and A3), shown in Figure 18.

The PSW specimens were comprised of two main modifications to the GIB Fire Rated Systems [26]. The partition walls, with a 60-min fire-resistance rating (GBS60), underwent: 1) removal of the top track anchors within the periphery of wall junctions to allow bowing of the tracks at these intersections under relative displacements, and 2) fixing of the gypsum plasterboards to the bottom tracks between each stud (not to the top tracks) so that the plasterboards remain stationary while the steel-studs slide within the steel-tracks under seismic actions. Further details on the PSW specimens and their seismic performance under bi-directional lateral cyclic drifts can be found in [30].

Basic comparisons in terms of force-displacement backbone, energy dissipation, damping coefficient, and secant stiffness degradation between the reported results of PSW specimens and the tested TFW specimen herein are shown in Figure 19.

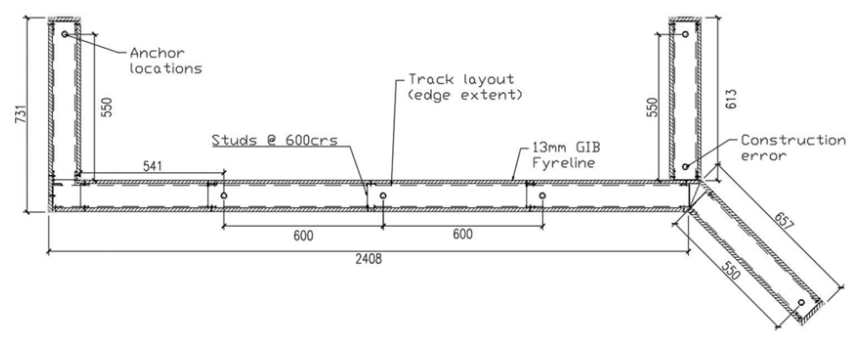

(a) Specimen A1 and A2- Plan.

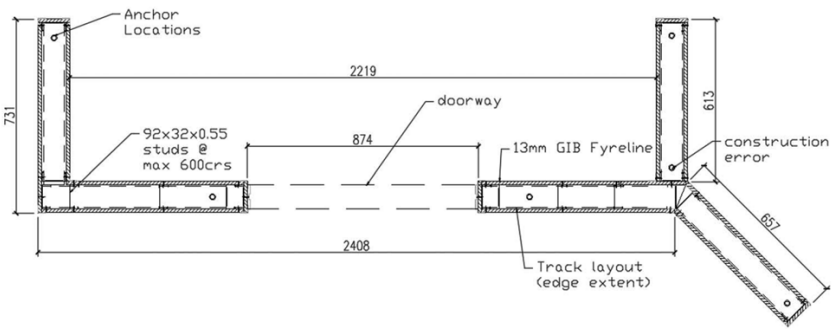

(b) Specimen A3 -Plan.

Figure 18: Steel-framed "partly-sliding" internal partition wall specimens tested by [30].

From Figure 19a, it can be observed that the ultimate strength of the TFW specimen is about twice of that of the PSW specimens. The post-peak downward slope of the load-displacement envelope of TFW indicates a ductile failure mode with significant strength degradation. Nevertheless, the wall was able to be reloaded multiple displacement cycles beyond the peak response and provided a hysteretic damping beyond 4\% (see Figure 19c). The forces at the final drift cycles for the TFW (after detachment of the gypsum plasterboards from the timber-frame) and the PSW (after the buckling of the steel frame with partial damage to plasterboards) specimens are similar. This implies that the contribution of the timber-framing only to the lateral load resistance of the TFW specimen is not that significant compared to the whole PSW specimen. Therefore, the differences in the forces in the earlier cycles of the loading protocol can be attributed to the stiff screw connections between the plasterboards and timber-studs as compared to flexible screw connections between plasterboards and thin steel-stud flanges.

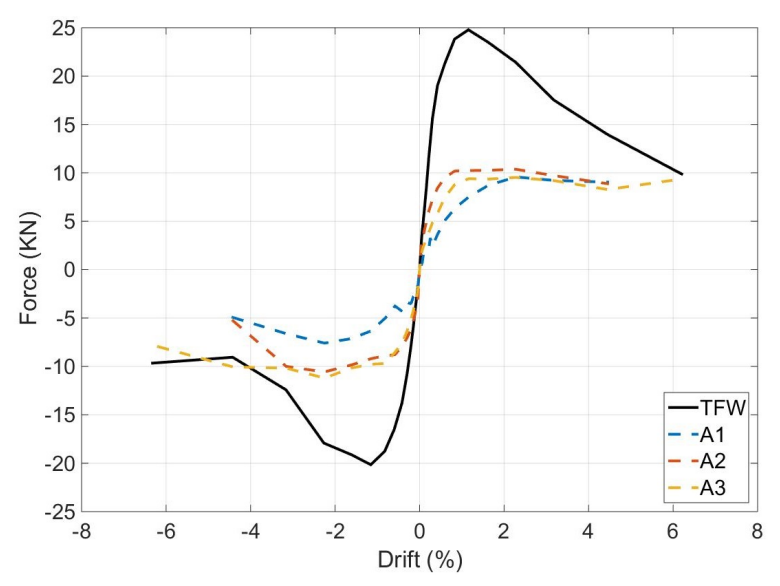

(a) Backbone curves.

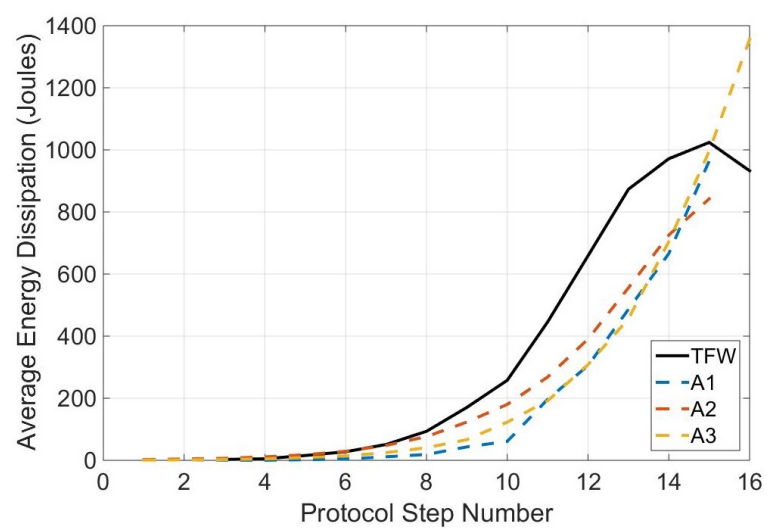

(b) Average energy dissipation.

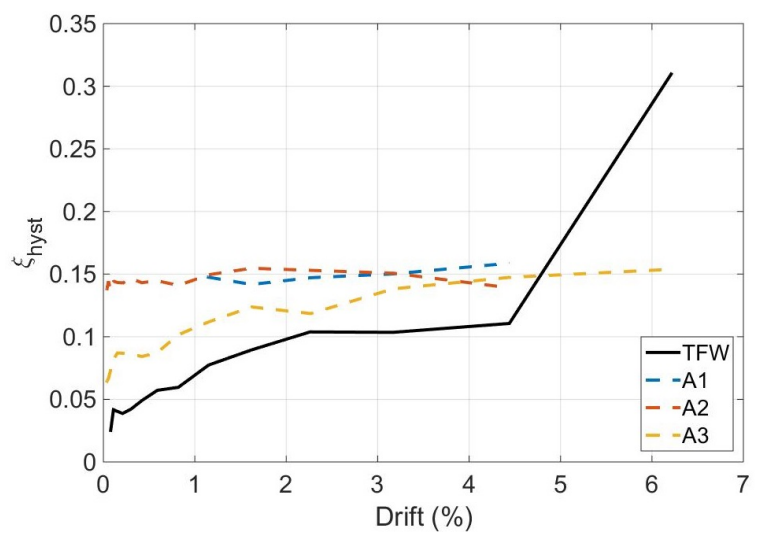

(c) Equivalent viscous damping coefficient.

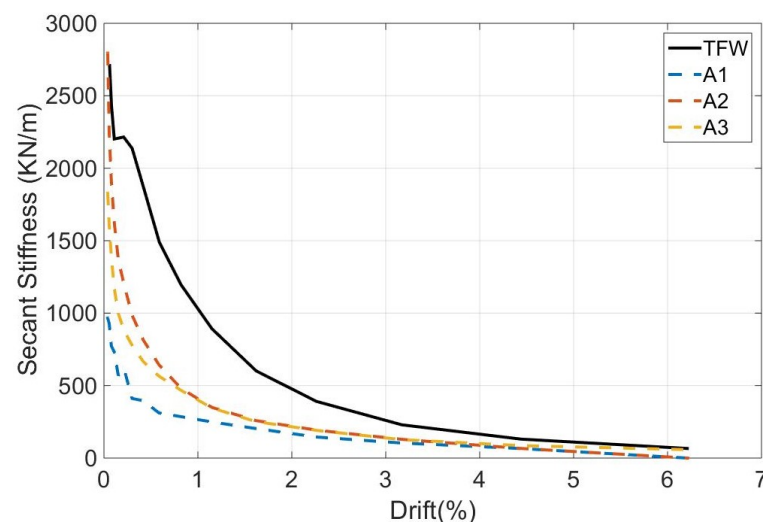

(d) Secant-stiffness degradation.

Figure 19: Comparison between TFW and PSW (A1, A2, and A3) specimens from [30]. 
Figure $19 \mathrm{~b}$ compares the average energy dissipated by the different specimens, which is calculated by taking the mean of the area under the first and second cycles of the hysteretic forcedisplacement loops for a given drift amplitude using the trapezium method. The energy dissipation of TFW shows a sharp increase between $0.60 \%$ and $2.00 \%$ inter-story drifts whereas there is a gradual increase of energy dissipation in the PSW specimens. This can be attributed to more widespread screw failures and cracking in the gypsum plasterboard within this inter-story drift range in the TFW specimen than in the PSW specimens. This suggests that in an earthquake, a PSW is likely to suffer less visible damage to screw connections than a TFW partition wall would.

Figure $19 \mathrm{c}$ plots the equivalent viscous damping coefficient $\xi_{\text {hyst }}$ at each loading step calculated using equation 23 [72].

$$
\xi_{\text {hyst }}=\frac{A_{h}}{2 \pi F_{m} \Delta_{m}}
$$

where $A_{h}, F_{m}$ and $\Delta_{m}$ are the energy absorbed during a complete cycle, the maximum force experienced in the cycle and the maximum displacement experienced in the cycle, respectively. As can be noticed in Figure 19c, the damping coefficient in the TFW wall rises sharply during the final cycles after $4 \%$ drift due to the buckling and detachment of the plasterboards.

Figure 19d compares the secant stiffness (calculated by dividing the maximum force by the imposed displacement for a given cycle) of the four specimens. It can be observed that all specimens suffer a gradual degradation of stiffness at higher drifts due to progressive damage.

The onset drifts for DS1 and DS2 for TFW were $0.51 \%$ and $1.40 \%$, respectively, versus $0.36 \%$ and $0.36 \%$ for specimens A1 and $\mathrm{A} 2$ and $0.26 \%$ and $0.26 \%$ for specimen $\mathrm{A} 3$, respectively. Early damage to PSW has been attributed to the top track pushing against the plasterboard lining. In all three specimens: 1) the end of the $\mathrm{RW}_{\mathrm{L}}$ wall was the first to suffer damage to the plasterboard, and 2) the end of the $\mathrm{RW}_{\mathrm{Y}}$ wall performed better in terms of plasterboard damage.

It can be observed that both the TFW and PSW specimens suffered damage quite early at low drift levels. However, the onset drifts for DS1 and DS2 could be delayed until $0.67 \%$ and $1.86 \%$ drift, respectively, when gypsum plasterboard partitions with "seismic gaps" (with a total vertical gap of $22 \mathrm{~mm}$ ) were tested under similar configurations and loading protocols [31]. Therefore, it is beneficial to provide some seismic reliefs or gaps $[18,31,64-66,73]$ in partition walls to avoid premature damage by delaying their interaction with the primary structure during earthquakes.

\section{CONCLUSIONS}

This paper presents the results of a theoretical and experimental study into the seismic performance of an interior timberframed partition wall constructed with details commonly used in New Zealand commercial construction and subjected to unidirectional quasi-static cyclic loading. The oblique orientation of the specimen allowed the examination of the bi-directional performances of the partitions.

Theoretical equations either derived based on linear elastic analyses or proposed in published literature for estimating/predicting the strength, stiffness, displacements, and different damage states of plasterboards partition walls were scrutinized and modified based on recently published research. Moreover, theoretical expressions to determine the required horizontal and vertical spacing of the screws to avoid screw failures before damage to plastered-joint between plasterboards during an earthquake were also derived.

A timber-framed plasterboard wall specimen comprising wall segments of different configurations was tested to determine the drift limits at which different levels of damage occur in such walls and to verify the accuracy of the theoretical equations. The signs of damage states DS1 (screw failures) and DS2 (corner crushing of plasterboards) initiated in the tested specimen at interstory drifts of $0.51 \%$ and $1.40 \%$, respectively. The theoretical estimates of the drifts at which the shear strength of the wall is reached, and the plasterboard suffered diagonal buckling failure were found to reasonably approximate the experimental results.

The tested interior timber-framed partition wall's behaviour was also compared with that of "partly-sliding" steel-framed partition walls tested under the same setup. The strength, stiffness, energy dissipation, and damping of the timber-frame partition wall were compared to those of similarly configured steel-framed "partlysliding" partition walls. These comparisons suggest that there is a significant difference in the damage pattern and ultimateshear capacity between these specimens. However, overall, the timber-framed partition wall failed in ductile fashion as that of the steel-framed wall except during the final cycle, where the failure mode was brittle.

Moreover, when the onset drifts corresponding to damage states DS1 and DS2 of these wall types ("timber-framed" and "partlysliding") were compared with the steel-framed partitions with "seismic gaps", they were found to suffer damage at relatively low inter-story drift. Therefore, intermediate "seismic gaps" in partition walls can lead to better performance by delaying their interaction with the primary structure during earthquakes, which avoids any premature damage.

\section{ACKNOWLEDGMENTS}

The work presented in this paper has been partly funded by the International Collaborative Research program of the Disaster Prevention Research Institute, Kyoto University under Project Number 28W-03 (PI: Timothy Sullivan), the NZ Property Council, and Quake Centre. This project was partially supported by QuakeCoRE, a New Zealand Tertiary Education Commissionfunded Centre. This is QuakeCoRE publication number 0637. QuakeCentre is greatly acknowledged for providing scholarship from the Building Innovation Partnership (BIP) program funded by the Ministry of Business, Innovation and Employment (MBIE). Gratitude is expressed to industry partner Winstone Wallboards Ltd. for their professional support. Special thanks are due to all the technical staff for their assistance and support at the University of Canterbury Laboratories.

\section{REFERENCES}

1 Villaverde R (1997). "Seismic design of secondary structures: state of the art". Journal of Structural Engineering, 123(8): 1011-1019. https://doi.org/10.1061/(ASCE)07339445(1997)123:8(1011)

2 ATC (2009). "ATC-69: Reducing the Risks of Nonstructural Earthquake Damage, State-of-the-Art and Practice Report". Applied Technology Council (ATC), California, US, https: //www.atcouncil.org/pdfs/SOAReport.pdf.

3 FEMA (2005). "FEMA 74-FM: Earthquake Hazard Mitigation for Nonstructural Elements Field Manual". Federal Emergency Management Agency (FEMA), US, https: //mitigation.eeri.org/files/FEMA74_FieldManual.pdf.

4 Taghavi S and Miranda E (2003). "Response Assessment of Nonstructural Building Elements". PEER 2003/05, Pacific Earthquake Engineering Research Center, University of Cal- 
ifornia Berkeley, US, https://peer.berkeley.edu/sites/default/ files/0305_s._taghavi_e._miranda_.pdf.

5 Khakurel S, Dhakal RP, Yeow TZ and Saha SK (2020). "Performance group weighting factors for rapid seismic loss estimation of buildings of different usage". Earthquake Spectra, 36(3): 1141-1165. https://doi.org/10.1177/ 8755293019901311

6 Achour N, Miyajima M, Kitaura M and Price A (2011). "Earthquake-induced structural and nonstructural damage in hospitals". Earthquake Spectra, 27(3): 617-634. https: //doi.org/10.1193/1.3604815

7 Kao A, Soong T and Vender A (1999). "Nonstructural Damage Database". MCEER-99-0014, Multidisciplinary Center for Earthquake Engineering Research (MCEER), Buffalo, NY, US, https://www.eng.buffalo.edu/mceer-reports/99/990014.pdf.

8 Bachman R (2004). "The ATC-58 project plan for non-structural components". International Workshop on Performance-Based Seismic Design, Concepts and Implementation, Bled, Slovenia.

9 Filiatrault A, Christopoulos C and Stearns C (2002). "Guidelines, Specifications, and Seismic Performance Characterization of Nonstructural Building Components and Equipment". PEER 2002/05, Pacific Earthquake Engineering Research Center (PEER), University of California, Berkeley, US, https://peer.berkeley.edu/sites/default/files/0205_a. _filiatrault_c._christopoulos_c._stearns.pdf.

10 Kircher CA (2003). "It makes dollars and sense to improve nonstructural system performance". ATC29-2 Seminar on Seismic Design, Performance, and Retrofit of Non-structural Components in Critical Facilities, Newport Beach, California, US.

11 Naumoski N, Foo S and Saatcioglu M (2002). Seismic hazard assessment and mitigation for buildings' functional and operational components: a Canadian perspective. ISBN 0 662-35206-8, University of Ottawa, Canada, https://www. publicsafety.gc.ca/lbrr/archives/cn3210-eng.pdf.

12 Echevarria A, Zaghi A, Soroushian S and Maragakis M (2012). "Seismic fragility of suspended ceiling systems". 15th World Conference on Earthquake Engineering (15WCEE), https://www.iitk.ac.in/nicee/wcee/article/ WCEE2012_4325.pdf.

13 Elsesser E (1984). "Life hazards created by nonstructural elements". Nonstructural Issues of Seismic Design and Construction, 84(04): 27-36.

14 Baird A, Tasligedik AS, Palermo A and Pampanin S (2014). "Seismic performance of vertical nonstructural components in the 22 February 2011 Christchurch earthquake". Earthquake Spectra, 30(1): 401-425. https://doi.org/10.1193/ 031013EQS067M

15 Dhakal RP (2010). "Damage to non-structural components and contents in 2010 Darfield earthquake". Bulletin of the New Zealand Society for Earthquake Engineering, 43(4): 404-411. https://doi.org/10.5459/bnzsee.43.4.404-411

16 Dhakal RP, MacRae GA and Hogg K (2011). "Performance of ceilings in the February 2011 Christchurch earthquake". Bulletin of the New Zealand Society for Earthquake Engineering, 44(4): 379-389. https://doi.org/10.5459/bnzsee.44. 4.377-387

17 Dhakal RP, Pourali A, Tasligedik AS, Yeow T, Baird A, MacRae G, Pampanin S and Palermo A (2016). "Seismic performance of non-structural components and contents in buildings: an overview of NZ research". Earthquake Engineering and Engineering Vibration, 15(1): 1-17. https://doi.org/10.1007/s11803-016-0301-9

18 AWCI (2018). "Code of practice for the seismic design and installation of non-structural internal walls and partitions". Association of Wall and Ceiling Industries (AWCI), New Zealand, https://awci.org.nz/wp-content/uploads/COPInternal-Walls-and-Partitions-coloured.pdf.

19 BNZSEE (2010). Darfield Earthquake Special Issue 43. Bulletin of the New Zealand Society for Earthquake Engineering (BNZSEE), New Zealand.

20 BNZSEE (2011). Darfield Earthquake Special Issue 44. Bulletin of the New Zealand Society for Earthquake Engineering (BNZSEE), New Zealand.

21 EQC/GNS (2012). GeoNet-Geological Hazard Information for New Zealand. http://www.geonet.org.nz (Accessed 22 April 2020).

22 Martin R and Matthew C (2017). "Physical Characteristics of New Non-Residential Buildings". Study Report SR368, Building Research Association of New Zealand (BRANZ), Porirua, New Zealand, https://d39d3mj7qio96p.cloudfront. net/media/documents/SR368_Characteristics_of_new_ non_residential_buildings_2015.pdf.

23 Beacon Pathway (2008). "New Zealand House Typologies to Inform Energy Retrofits". Report No. EN6570(9), Beacon Pathway, Auckland, New Zealand, https://beaconpathway.co. nz/images/uploads/Final_Report_EN6570(9)_NZ_House_ Typologies_to_Inform_Energy_Retrofits.pdf.

24 Vance VL (1997). "Effects of Architectural Walls on Building Response to Ambient and Seismic Excitations". $\mathrm{PhD}$ Dissertation, Stanford University, Stanford, CA, US, https: //purl.stanford.edu/cy467cg4958.

25 AS/NZS (2018). "AS/NZS2558: Gypsum Plasterboard". Standards Australia / Standards New Zealand.

26 GIB (2018). GIB-site-guide. http://www.gib.co.nz (Accessed 05 March 2020).

27 Elephant Plasterboard (2015). Elephant Plasterboard in stallation guide. http://www.elephantplasterboard.co.nz (Accessed 05 March 2020).

28 USG Boral (2016). Plasterboard installation manual. http:// www.elephantplasterboard.co.nz (Accessed 03 March 2020).

29 AS/NZS (2017). "AS/NZS2589: Gypsum LiningsApplication and Finishing". Standards Australia / Standards New Zealand.

30 Mulligan J, Sullivan T and Dhakal R (2020a). "Experimental seismic performance of partly-sliding partition walls". Journal of Earthquake Engineering: 1-26. https://doi.org/10. 1080/13632469.2020.1733139

31 Mulligan J, Sullivan T and Dhakal R (2020b). "Experimental seismic performance of plasterboard partition walls with seismic gaps". Bulletin of the New Zealand Society for Earthquake Engineering, 53(4): 175188, https://www.bulletin.nzsee.org.nz/index.php/bnzsee/ article/download/1501/1407.

32 Filiatrault A, Fischer D, Folz B, Uang C and Seible F (2001) "Shake table test of a two-story woodframe house". Element 1 Research Meeting. https://doi.org/10.1061/40558(2001)176

33 Gatto K and Uang CM (2002). "Cyclic Response of Woodframe Shearwalls: Loading Protocol and Rate of Loading Effects". Consortium of Universities for Research in Earthquake Engineering (CUREE), Richmond, CA, US, https://www.curee.org/publications/woodframe/ downloads/CUREEpub_W-13.pdf.

34 Gad EF, Chandler AM, Duffield CF and Stark G (1999). "Lat- 
eral behavior of plasterboard-clad residential steel frames". Journal of Structural Engineering, 125(1): 32-39. https: //doi.org/10.1061/(ASCE)0733-9445(1999)125:1(32)

35 McMullin KM and Merrick D (2002). "Seismic Performance of Gypsum Walls: Experimental Test Program". Consortium of Universities for Research in Earthquake Engineering (CUREE), Richmond, CA, US, https://www.curee.org/publications/woodframe/downloads/ CUREEpub_W-15.pdf.

36 Oliva MG (1990). "Racking Behavior of Wood-Frame Gypsum Panels Under Dynamic Load". Report No. UCB/EERC85/06, Earthquake Engineering Research Center, University of California, Berkeley, CA, US.

37 Patton-Mallory M, Wolfe RW, Soltis LA and Gutkowski RM (1985). "Light-frame shear wall length and opening effects". Journal of Structural Engineering, 111(10): 2227 2239. https://doi.org/10.1061/(ASCE)0733-9445(1985)111: 10(2227)

38 Wolfe RW (1983). Contribution of Gypsum Wall Board to Racking Resistance of Light-Frame Walls. US Department of Agriculture, Forest Service, Forest Products Laboratory.

39 Arnold AE, Uang CM and Filiatrault A (2003a). "Cyclic Behavior and Repair of Stucco and Gypsum Woodframe Walls: Phase I". Consortium of Universities for Research in Earthquake Engineering (CUREE), Richmond, CA, US, https:// curee.org/projects/EDA/docs/CUREE-EDA03-public.pdf.

40 Arnold AE, Uang CM and Filiatrault A (2003b). "Cyclic Behavior and Repair of Stucco and Gypsum Woodframe Walls: Phase II". Consortium of Universities for Research in Earthquake Engineering (CUREE), Richmond, CA, US, http: //www.curee.org/projects/EDA/docs/SSRP-2002-07.pdf.

41 van de Lindt JW (2008). "Experimental investigation of the effect of multiple earthquakes on woodframe structural integrity". Practice Periodical on Structural Design and Construction, 13(3): 111-117. https://doi.org/10.1061/(ASCE) 1084-0680(2008)13:3(111)

42 Memari AM and Solnosky RL (2014). "In-plane shear performance of wood-framed drywall sheathing wall systems under cyclic racking loading”. Open Journal of Civil Engineering, 2014. https://doi.org/10.4236/ojce.2014.41006

43 Tasligedik AS (2014). "Damage Mitigation Strategies for Non-structural Infill Walls". PhD Dissertation, Department of Civil and Natural Resources Engineering, University of Canterbury, Christchurch, New Zealand, https://ir.canterbury.ac.nz/bitstream/handle/10092/ 9462/thesis_fulltext.pdf?sequence $=1$.

44 Golledge B, Clayton T and Reardon G (1992). "Racking performance of plasterboard-clad steel stud walls". 11th International Specialty Conference on Cold-Formed Steel Structures, https://scholarsmine.mst.edu/cgi/viewcontent. cgi article $=1794 \&$ context $=$ isccss .

45 Liew Y, Duffield C and Gad E (2002). "The influence of plasterboard clad walls on the structural behaviour of low rise residential buildings." Electronic Journal of Structural Engineering, 2(1): 1-16.

46 Tarpy Jr TS (1984). "Shear resistance of steel stud wall panels: a summary report". 7th International Specialty Conference on Cold.Formed Steel Structures, University of Missouri-Rolla, St.louis. Missouri, US.

47 Swensen S, Deierlein G and Miranda E (2016). "Behavior of screw and adhesive connections to gypsum wallboard in wood and cold-formed steel-framed wallettes". Journal of Structural Engineering, 142(4): E4015002. https://doi.org/ 10.1061/(ASCE)ST.1943-541X.0001307
48 Retamales R, Davies R, Mosqueda G and Filiatrault A (2013). "Experimental seismic fragility of cold-formed steel framed gypsum partition walls". Journal of Structural Engineering, 139(8): 1285-1293. https://doi.org/10.1061/ (ASCE)ST.1943-541X.0000657

49 Restrepo JI and Bersofsky AM (2011). "Performance characteristics of light gage steel stud partition walls". Thin-Walled Structures, 49(2): 317-324. https://doi.org/10.1016/j.tws. 2010.10.001

50 Amer S, Hamoush S and Abu-Lebdeh T (2016). "In-plane performance of gypsum board partition wall systems subjected to cyclic loadings". Journal of Constructional Steel Research, 124: 23-36. https://doi.org/10.1016/j.jcsr.2016.05. 013

51 Nie S, Zhou T, Zhang Y, Zhang B and Wang S (2020). "Investigation on the design method of shear strength and lateral stiffness of the cold-formed steel shear wall". Mathematical Problems in Engineering, 2020. https://doi.org/doi.org/10. 1155/2020/8959712

52 Innella F, Luo FJ and Bai Y (2018). "Capacity of screw connections between plasterboard panels and cold-formed steel for modular buildings". Journal of Architectural Engineering, 24(4): 04018031. https://doi.org/10.1061/(ASCE)AE. 1943-5568.0000338

53 Chen W, Ye J and Chen T (2016). "Design of cold-formed steel screw connections with gypsum sheathing at ambient and elevated temperatures". Applied Sciences, 6(9): 248. https://doi.org/10.3390/app6090248

54 Liu A and Shelton RH (2018). "Seismic Effects of Structural Irregularity of Light Timber-framed Buildings". Study Report SR404, Building Research Association of New Zealand (BRANZ), New Zealand, https://d39d3mj7qio96p.cloudfront.net/media/documents/ SR404_Seismic_effects_of_structural_irregularity.pdf.

55 Vieira Jr LC and Schafer BW (2012). "Lateral stiffness and strength of sheathing braced cold-formed steel stud walls". Engineering Structures, 37: 205-213. https://doi. org/10.1016/j.engstruct.2011.12.029

56 Doghri I (2013). Mechanics of deformable solids: linear, nonlinear, analytical and computational aspects. Springer Science and Business Media.

57 Gypsum Association (2019). "GA-235-2019: Gypsum Board Typical Mechanical and Physical Properties". Gypsum Association, Silver Spring, MD, US, https://www.americangypsum.com/sites/default/files/ documents/GA-235\%20Gypsum\%20Board\%20Typical\% 20Mechanical\%20and\%20Physical\%20Properties.pdf.

58 Thurston SJ (1993). "Report on racking resistance of long sheathed timber framed walls with openings". Study Report SR54, Building Research Association of New Zealand (BRANZ), New Zealand, https://www.branz.co.nz/ documents/547/SR54_Report_on_racking_resistance_of_ long_sheathed_timber_framed_walls_with.pdf.

59 Standards New Zealand (1992). "NZS3603: New Zealand Timber Structures Standard". Standards New Zealand, Wellington, New Zealand.

60 Thurston SJ (2004). "BRANZ Test and Evaluation Method EM3-V2 for Bracing Rating of Walls to NZS 3604". Study Report SR131, Building Research Association of New Zealand (BRANZ), New Zealand, https://d39d3mj7qio96p.cloudfront.net/media/documents/ SR131_BRANZ_test_and_evaluation_method_EM3V2_for_bracing_rating_of_walls_to_NZS_3604.pdf.

61 Dowrick D and Smith P (1986). "Timber sheathed walls 
for wind and earthquake resistance". Bulletin of the New Zealand Society for Earthquake Engineering, 19(2): 123134. https://doi.org/10.5459/bnzsee.19.2.123-134

62 Filiatrault A and Foschi R (1991). "Static and dynamic tests of timber shear walls fastened with nails and wood adhesive". Canadian Journal of Civil Engineering, 18(5): 749-755. https://doi.org/10.1139/191-091

63 Memari AM, Kasal B, Manbeck HB and Adams AR (2009). "Lateral load resistance evaluation of wood-and steel-stud partition shear walls". Journal of Architectural Engineering, 15(4): 122-130. https://doi.org/10.1061/(ASCE)10760431(2009)15:4(122)

64 Lee TH, Kato M, Matsumiya T, Suita K and Nakashima M (2007). "Seismic performance evaluation of non-structural components: drywall partitions". Earthquake Engineering and Structural Dynamics, 36(3): 367-382. https://doi.org/ 10.1002/eqe.638

65 Pali T, Macillo V, Terracciano MT, Bucciero B, Fiorino $\mathrm{L}$ and Landolfo R (2018). "In-plane quasi-static cyclic tests of nonstructural lightweight steel drywall partitions for seismic performance evaluation". Earthquake Engineering and Structural Dynamics, 47(6): 1566-1588. https: //doi.org/10.1002/eqe.3031

66 Magliulo G, Petrone C, Capozzi V, Maddaloni G, Lopez P and Manfredi G (2014). "Seismic performance evaluation of plasterboard partitions via shake table tests". Bulletin of Earthquake Engineering, 12(4): 1657-1677. https://doi.org/ 10.1007/s10518-013-9567-8

67 Sucuoğlu H and Vallabhan CG (1997). "Behaviour of window glass panels during earthquakes". Engineering Structures, 19(8): 685-694. https://doi.org/10.1016/S01410296(96)00130-7

68 McCutcheon WJ (1985). "Racking deformations in wood shear walls". Journal of Structural Engineering, 111(2): 257269. https://doi.org/10.1061/(ASCE)0733-9445(1985)111: 2(257)

69 McMullin KM and Merrick DS (2007). "Seismic damage thresholds for gypsum wallboard partition walls". Journal of Architectural Engineering, 13(1): 22-29. https://doi.org/10. 1061/(ASCE)1076-0431(2007)13:1(22)

70 FEMA (2007). "FEMA 461-Interim protocols for Determining Seismic Performance Characteristics of Structural and Nonstructural Components". Federal Emergency Management Agency (FEMA), Washington, D.C., US, https: //www.atcouncil.org/pdfs/FEMA461.pdf.

71 Petrone C, Magliulo G and Manfredi G (2016). "Mechanical properties of plasterboards: experimental tests and statistical analysis". Journal of Materials in Civil Engineering, 28(11): 04016129. https://doi.org/10.1061/(ASCE)MT.1943-5533. 0001630

72 Calvi G, Priestley M and Kowalsky M (2007). DisplacementBased Seismic Design of Structures. IUSS Press, Pavia, Italy, http://giec.espe.edu.ec/wp-content/uploads/2013/09/ Priestley-Calvi-y-Kowalsky.pdf.

73 GIB (2017). Gypsum Plasterboard Lined Partitions in Commercial Construction Update. http://www.gib.co.nz (Accessed 10 April 2020). 